\title{
Temporal changes of cytochrome P450 (Cyp) and eicosanoid-related gene expression in the rat brain after traumatic brain injury
}

\author{
Matthew Birnie ${ }^{1}$, Ryan Morrison ${ }^{1}$, Ramatoulie Camara ${ }^{1}$ and Kenneth I Strauss ${ }^{1,2^{*}}$
}

\begin{abstract}
Background: Traumatic brain injury (TBI) induces arachidonic acid (ArA) release from cell membranes. ArA metabolites form a class of over 50 bioactive eicosanoids that can induce both adaptive and/or maladaptive brain responses. The dynamic metabolism of ArA to eicosanoids, and how they affect the injured brain, is poorly understood due to their diverse activities, trace levels, and short half-lives. The eicosanoids produced in the brain postinjury depend upon the enzymes present locally at any given time. Eicosanoids are synthesized by hemecontaining enzymes, including cyclooxygenases, lipoxygenases, and arachidonate monoxygenases. The latter comprise a subset of the cytochrome P450 "Cyp" gene family that metabolize fatty acids, steroids, as well as endogenous and exogenous toxicants. However, for many of these genes neither baseline neuroanatomical nor injury-related temporal expression have been studied in the brain.

In a rat model of parietal cortex TBI, Cyp and eicosanoid-related mRNA levels were determined at 6 h, 24 h, 3d, and $7 \mathrm{~d}$ postinjury in parietal cortex and hippocampus, where dynamic changes in eicosanoids have been observed. Quantitative real-time polymerase chain reaction with low density arrays were used to assay 62 rat Cyps, 37 of which metabolize ArA or other unsaturated fatty acids; 16 eicosanoid-related enzymes that metabolize ArA or its metabolites; 8 eicosanoid receptors; 5 other inflammatory- and recovery-related genes, plus 2 mouse Cyps as negative controls and 3 highly expressed "housekeeping" genes.

Results: Sixteen arachidonate monoxygenases, 17 eicosanoid-related genes, and 12 other Cyps were regulated in the brain postinjury ( $p<0.05$, Tukey HSD). Discrete tissue levels and distinct postinjury temporal patterns of gene expression were observed in hippocampus and parietal cortex.

Conclusions: The results suggest complex regulation of ArA and other lipid metabolism after TBI. Due to the temporal nature of brain injury-induced Cyp gene induction, manipulation of each gene (or its products) at a given time after TBI will be required to assess their contributions to secondary injury and/or recovery. Moreover, a better understanding of brain region localization and cell type-specific expression may be necessary to deduce the role of these eicosanoid-related genes in the healthy and injured brain.
\end{abstract}

Keywords: Cytochrome P450 genes, Arachidonic acid metabolic genes, Hippocampus, Parietal cortex, qPCR low density array, In situ hybridization

\footnotetext{
* Correspondence: kenneth.strauss@hc.msu.edu

'University of Cincinnati College of Medicine, 231 Albert Sabin Way ML 515, 45267 Cincinnati, OH, USA

${ }^{2}$ Present Address: Michigan State University College of Human Medicine, 333 Bostwick Ave NE, 49503 Grand Rapids, MI, USA
} 


\section{Background}

The conversion of arachidonic acid (ArA) to over 50 bioactive eicosanoids is catalyzed by a variety of enzymes including heme-containing cyclooxygenases, prostanoid synthases, lipoxygenases, and arachidonate monoxygenases. The latter, arachidonate hydroxylases and epoxygenases, comprise a subset of the cytochrome $\mathrm{P} 450$ or "Cyp" gene family of evolutionarily related proteins that metabolize polyunsaturated fatty acids, steroids, as well as endogenous and exogenous toxicant molecules in organisms from bacteria to primates [1].

These Cyp arachidonate monoxygenases produce hydroxyeicosatetraenoic acids and epoxyeicosatrienoic acids (HETEs and EETs) that modulate a variety of responses in the healthy and injured brain. HETEs and EETs have been implicated in the physiology of the febrile response, stimulation of hypothalamic somatostatin release, pituitary vasopressin, oxytocin and luteinizing hormone release, pancreatic glucagon and insulin release, inhibition of platelet aggregation, inhibition of the activity of $\mathrm{Na}^{+} \mathrm{K}^{+}$-ATPase in the nephron and corneal epithelium, regulation of blood pressure, vasodilation of local microcirculation in the kidney, intestine, heart and brain [2-5]. Their activities include cerebral vasoconstriction [6-10] and vasodilatation [11-15], possibly by modulation of monovalent and divalent ion flux [6,16-24].

Many of these Cyps are induced during inflammatory challenge, however recent evidence suggests that their products may diminish inflammation [2,25-27]. A number of neuron-specific effects have also been ascribed to HETEs and EETs, e.g., 12-HETE neuroprotection from glutamate-mediated cell death [28] and 14,15-EET acceleration of axonal growth [29] in primary cell cultures. In addition, EETs recently have been implicated in central nociceptive and hyperalgesic responses, with different EETs potentially moderating different effects on pain perception [22,30-34].

Brain injuries activate phospholipases and result in the release of fatty acids such as ArA from damaged membranes [35-37]. Within $48 \mathrm{~h}$ of traumatic brain injury (TBI), free fatty acid levels increased in human cerebral spinal fluid (CSF), compared to neurologically unimpaired controls [38]. Arachidonic acid (20:4 $\omega-6)$ increased 1093\%; docosahexenoic acid (22:6 $\omega-3)$ 475\%; oleic acid (18:1) 492\%; myristic acid (14:0) 279\%; linoleic acid (18:2) 203\%; and palmitic acid (18:0) 175\%. ArA levels can remain elevated for days after TBI [36]. The eicosanoids formed in different brain regions in response to TBI change dynamically over the minutes, hours, and days postinjury, likely due to local alterations in the expression of their synthetic enzymes. Regulation of prostaglandin and leukotriene metabolites and many of their source enzymes in the brain and after TBI have been well described [39-50]. Dynamic changes in P450 eicosanoid levels also occur in the injured brain [15,41,51-57]. However, the production, enzymatic sources, and local regulation after brain injury of hydroxylases, epoxygenases and their products have been less well studied.

Local brain HETE and EET levels have not been well described due to their trace levels, short half-lives, and closely related chemical structures. Moreover, because of the historic lack of gene-specific antibodies and molecular probes, it has been difficult to characterize the regulation of individual Cyp genes in this large family. Completion of the sequencing of the rat genome [58] has yielded molecular probes specific for each identified (and predicted) Cyp gene family member. Many quantitative real-time polymerase chain reaction (qPCR) probe sets have now been empirically validated and are commercially available. This study utilizes qPCR to quantify multiple Cyps and other eicosanoid-related gene changes in the rat hippocampus and parietal cortex at several time points after TBI. Determining the regulation of these genes and their eicosanoid products in specific brain regions and at specific time points after brain injury are the first steps in the investigation of their contribution to secondary brain damage and/or recovery of function.

\section{Results}

Custom low density array qPCR assays, normalization and negative controls

Parietal cortex and hippocampal cDNA from naïve and brain-injured or sham-operated rats at $6 \mathrm{~h}, 24 \mathrm{~h}, 72 \mathrm{~h}$, or $168 \mathrm{~h}$ after surgery ( $\mathrm{n} \geq 3$ per group) were used to determine the expression profiles of 96 genes in custom low density arrays by qPCR (see Additional file 1: Table S1 for probe set identifiers). The assays included 62 rat Cyp genes (37 known to metabolize ArA or other unsaturated fatty acids), plus 2 mouse Cyps as negative controls; 16 eicosanoid-related genes that metabolize arachidonic acid or its primary metabolites; 8 eicosanoid receptor genes; as well as 5 inflammatory- or recovery-related genes; plus 3 highly expressed housekeeping genes.

Starting with equal quantities of total RNA, the housekeeping genes Ppia (peptidylprolyl isomerase A or cyclophilin-A, CYC); glyceraldehyde 3-phosphate dehydrogenase, and $18 \mathrm{~S}$ rRNA were examined first to determine which to use for normalization purposes. Ppia was the least variant (Additional file 2: Figure S1), and subsequent $\mathrm{qPCR} \mathrm{C}_{t}$ values for each target gene were normalized as the initial copy number ratio $\left(f_{\mathrm{i}}\right.$ that is proportional to $2^{-\Delta \mathrm{Ct}}$, see Methods) to compare expression of the same gene between specimens.

Two cross-species negative controls were included in this study to test for amplification specificity in the highly conserved cytochrome P450 gene family. Probe sets for mouse Cyp2c54 and Cyp2c50 yielded no detectable amplification products in nearly all specimens. 
Unexpectedly, the probe set for mouse Cyp2c54 showed expression in the injured hippocampus only at $24 \mathrm{~h}$, in all 3 rats from this treatment group. Upon closer scrutiny, 5 distinct rat sequences were found to have homology within the probe set of mouse Cyp2c54 (see Additional file 3). However, 3 of the rat genes examined in these analyses (Cyp2c12, Cyp2c13, Cyp2c37) showed no changes at any time point, and the 2 processed pseudogenes were not assayed. This result may characterize transient local expression of a pseudogene or a new rat Cyp homolog.

\section{Overview of gene expression changes}

Forty-five of the 96 genes studied showed time-dependent changes in cortex or hippocampus after TBI $(\mathrm{p}<0.05$, Tukey HSD, Table 1). Sixteen arachidonate-metabolizing Cyps (Table 1A) as well as 17 other eicosanoid-related genes (Table 1B) were temporally regulated in injured hippocampus and/or cortex. Moreover, several Cyps with other known functions were regulated in the brain after TBI (Table 1C). Over half of the genes examined (51/96) showed differential expression levels between parietal cortex and hippocampus ( $\mathrm{p}<0.05$, Tukey HSD, Additional file 1: Table S2). There were 12 genes showing sham effects; i.e., differences between naive mRNA levels and shams at one or more time points (Additional file 1: Table S3). These were due to anesthesia or surgical intervention, and might have masked injury-related mRNA changes.

\section{Temporal expression of eicosanoid-related expression after traumatic brain injury}

Of the genes found to change over time, expression patterns of arachidonate-metabolizing and eicosanoidrelated genes (Table 1A,B), as well as other Cyp genes (Table 1C) are presented below, organized by temporal pattern (i.e., time of onset and duration), with neuroanatomic differences noted for each.

Acute changes in mRNA levels were those initiated at $6 \mathrm{~h}$ or $24 \mathrm{~h}$ and did not persist at $72 \mathrm{~h}$ after TBI. In both hippocampus and parietal cortex, Ptgs 2 (cyclooxygenase-2, COX2) was increased at $6 \mathrm{~h}$ only. In hippocampus, acuteonly increases included Cyp $2 c 6$, Cyp $2 c 22$, Cyp $2 c 23$, Cyp2c54, Cyp2e1, Cyp4a1 and Hpgd. In cortex, acuteonly increases included Cyp4f18, Alox15, Alox5ap, Ptges, Ptgis and Ptgir.

Early- and delayed-onset transient changes after TBI were defined as those changes lasting more than $24 \mathrm{~h}$ but not after $72 \mathrm{~h}$ postinjury. These included Ptgs1 (72 h only) in both hippocampus and cortex; in hippocampus Ptger 2 (biphasic at $6 \mathrm{~h}, 72 \mathrm{~h}$ ) and Ptgir (6 to $72 \mathrm{~h}$ ); and in parietal cortex Cyp4b1 (Additional file 4: Figure S2), Pla2g4a (6 to $72 \mathrm{~h}$ ), Cyp2j3 and Tbxas1 (72 h only). It should be noted that changes detected at $72 \mathrm{~h}$ only might actually have been prolonged between $1 \mathrm{~d}$ to $6 \mathrm{~d}$ surrounding the $72 \mathrm{~h}$ timepoint.
Several mRNA levels changed acutely (within $24 \mathrm{~h}$ postinjury) and remained altered throughout the $7 \mathrm{~d}$ observation period. These included Cyp $4 b 1$ (Additional file 4: Figure S2), Cyp4a8 and Ptgfrn in hippocampus; Ptger4 and Cyp $4 x 1$ (the only mRNA consistently decreased) in parietal cortex. Levels of Lta $4 h$ mRNA were increased biphasically, at $6 \mathrm{~h}$ and again at $72 \mathrm{~h}$ to $168 \mathrm{~h}$ in parietal cortex.

A number of genes showed delayed-onset prolonged changes (from $72 \mathrm{~h}$ to $168 \mathrm{~h}$ postinjury, or at $168 \mathrm{~h}$ only). In hippocampus Alox5ap, Cyp2u1, Cyp4f5, Cyp4f6, Pla2g4a, Ptger4, and Tbxas1 were increased from $72 \mathrm{~h}$ to 168 h; whereas Cyp2j3, Cyp2j4, Ptges, Ptgis, Ptgdr, and $E p h x 1$ were increased at $168 \mathrm{~h}$ only. In both hippocampus and parietal cortex, Cyp26b1 and Ptgds2 increased at $168 \mathrm{~h}$ only. It should be noted that changes detected at $168 \mathrm{~h}$ only might have occurred as early as $4 \mathrm{~d}$ postinjury or only transiently around the $7 \mathrm{~d}$ endpoint of this study.

\section{Temporal expression of steroid metabolizing and other Cyp genes after traumatic brain injury}

Several other Cyp genes not known to metabolize ArA or polyunsaturated fatty acids showed altered levels after TBI (Table $1 \mathrm{C}$ ). Acute only changes from $6 \mathrm{~h}$ to $24 \mathrm{~h}$ postinjury were seen in the cortex for Cyp24a1 and Cyp27b1; and at $24 \mathrm{~h}$ only for Cyp3a18 in hippocampus. Transient changes were seen for Cyp11b3 and Cyp17a1 in hippocampus, and for Cyp $1 b 1$ in cortex. Acute-prolonged changes (6 h or $24 \mathrm{~h}$ through $168 \mathrm{~h}$ ) were observed for Cyp1a1 and Cyp7a1 in hippocampus. Several were upregulated in a delayed-prolonged manner, including Cyp1b1, Cyp2r1, Cyp20a1, Cyp27a1 and Cyp27b1 in hippocampus. Interestingly, Cyp2a2 mRNA appeared below detectable levels in the hippocampus in most sham and all naïve rats except at $24 \mathrm{~h}$ postinjury (suggesting gene induction), and 15/28 rats had below detectable levels in parietal cortex.

\section{Localization of Cyp2j4 and Cyp27a1 expression}

As a first step in localizing the expression of two brain injury regulated Cyps of diverse function, in situ hybridization histochemistry was used to visualize Cyp2j4 and Cyp27a1 expression at $7 \mathrm{~d}$ postinjury. Predominantly neuronal expression was seen for both Cyp2j4 and Cyp27a1 in neocortex. For Cyp2j4 mRNA, cortical, hippocampal and habenular regions showed intense staining primarily in what appeared to be neuronal cells, with only light staining in the thalamus. Light staining of perivascular and other cell types was evident bilaterally. Little to no staining was observed in the corpus callosum or other white matter structures. Expression appeared greatest in injured parietal (Figure 1A) and piriform cortex (Figure 1B), compared with both sham and contralateral brain regions, whereas cingulate cortex showed expression bilaterally 
Table 1 Changes in rat brain cyp and arachidonate-related gene expression after traumatic brain injury

\begin{tabular}{|c|c|c|c|c|c|c|c|c|}
\hline \multirow{2}{*}{$\begin{array}{l}\text { Gene } \\
\text { name }\end{array}$} & \multicolumn{4}{|c|}{$\begin{array}{l}\text { HIPPOCAMPUS, time } \\
\text { postinjury: }\end{array}$} & \multicolumn{4}{|c|}{$\begin{array}{l}\text { CORTEX, time } \\
\text { postinjury: }\end{array}$} \\
\hline & $6 \mathrm{~h}$ & $24 \mathrm{~h}$ & $72 \mathrm{~h}$ & $168 \mathrm{~h}$ & $6 \mathrm{~h}$ & $24 \mathrm{~h}$ & $72 \mathrm{~h}$ & $168 \mathrm{~h}$ \\
\hline & \multicolumn{8}{|c|}{ A. Arachidonate-related Cyps: mRNA fold-changes* } \\
\hline Cyp2c6 & $\mathrm{b}$ & $3.5 x$ & & & $\mathrm{~b}$ & $\mathrm{~b}$ & $\mathrm{~b}$ & $\mathrm{~b}$ \\
\hline Cyp2c22 & & $3 x$ & & & & & & \\
\hline Cyp2c23 & & $3 x$ & & & & & & \\
\hline Cyp2c54 & $\mathrm{b}$ & $3 x$ & $\mathrm{~b}$ & $\mathrm{~b}$ & $\mathrm{~b}$ & $\mathrm{~b}$ & $\mathrm{~b}$ & $\mathrm{~b}$ \\
\hline Cyp2e1 & & $2.5 x$ & & & & & & \\
\hline Cyp2j3 & & & & $2 x$ & & & $2 \mathrm{x}$ & {$[1.5 x]$} \\
\hline Cyp2j4 & & & {$[2 x]$} & $4 x$ & & & $2 x^{9}$ & {$[1.5 x]$} \\
\hline Cyp2u1 & & & $1.5 x$ & $2.5 x$ & & & & \\
\hline Сyp4a1 & & $3 x$ & & & & & & \\
\hline Сур4a8 & $2 x^{\pi}$ & $4 x^{n}$ & $7 x^{9}$ & $2 x^{\pi}$ & & & & \\
\hline Cyp4b1 & {$[3 x]$} & $6 x^{9}$ & $5 x$ & $9 x$ & $2 x^{\pi}$ & $3 x^{9}$ & $4 x^{9}$ & {$[1.5 x]$} \\
\hline Cyp4f5 & & & $1.5 x$ & $2 x$ & & & {$[1.5 x]$} & {$[1.5 x]$} \\
\hline Cyp4f6 & & & $1.5 x$ & $2 x$ & & & & \\
\hline Cyp4f18 & & & & & $3 x^{7}$ & {$[2 x]$} & {$[1.5 x]$} & \\
\hline Cyp4x 1 & & & & & $1 / 2 x^{9}$ & $1 / 2 x$ & {$[1 / 2 x]$} & $1 / 2 x^{9}$ \\
\hline Cyp26b1 & & & & $4 x^{\pi}$ & & & & $2.5 x$ \\
\hline
\end{tabular}

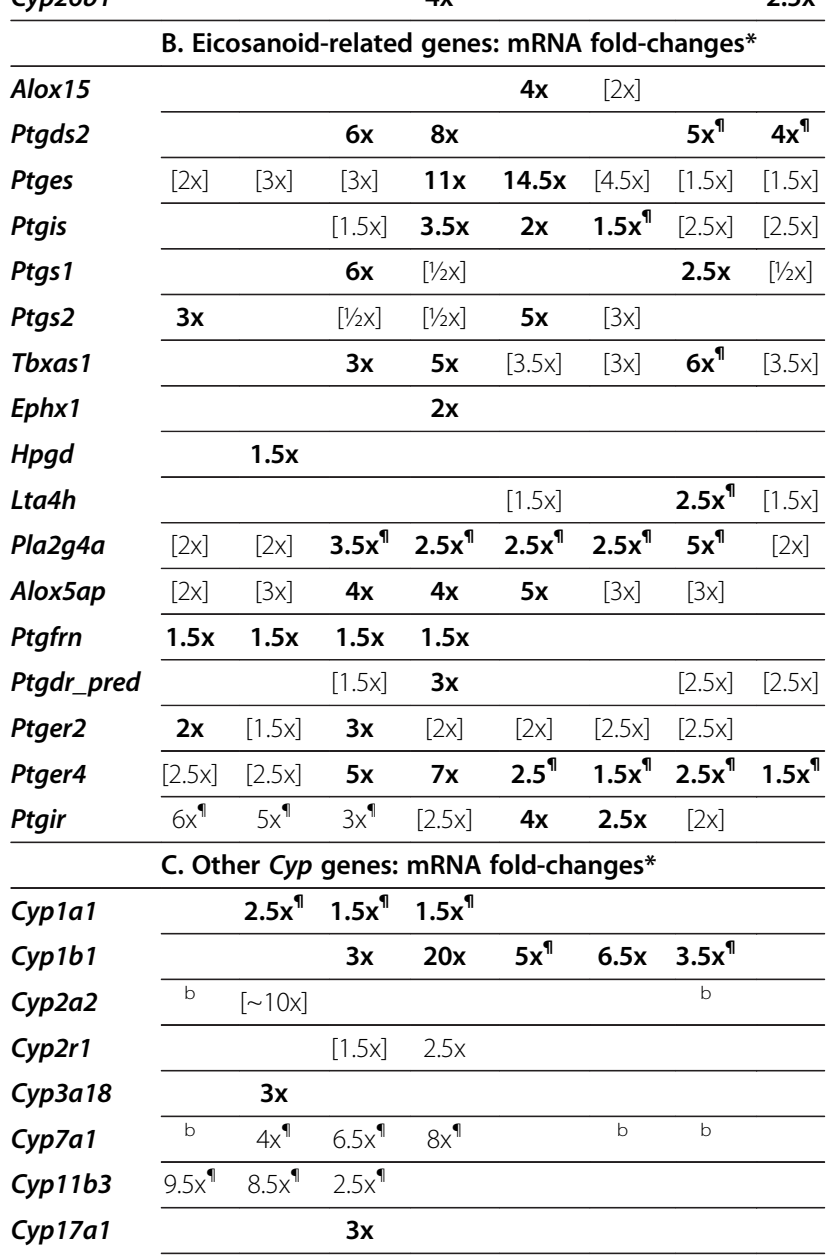

Table 1 Changes in rat brain cyp and arachidonate-related gene expression after traumatic brain injury (Continued)

\begin{tabular}{|c|c|c|c|c|c|c|c|c|}
\hline Cyp20a1 & & {$[2 x]$} & {$[2 x]$} & $2.5 x$ & & & & \\
\hline Cyp24a1 & & & & & $\sim 5.5 x^{9}$ & $\sim 7 x^{9}$ & b & \\
\hline Сур27a1 & {$[1 / 2 x]$} & & {$[3 x]$} & $9 x$ & & {$[1 / 2 x]$} & {$[1.5 x]$} & {$[2 x]$} \\
\hline Cур27b1 & & & & $2 x^{a}$ & $\sim 8 x^{n}$ & $\sim 11 \mathrm{x}^{n}$ & b & {$[\sim 2 x]$} \\
\hline
\end{tabular}

A: Arachidonate-related Cyps; B: Eicosanoid-related genes; C: Other Cyp genes. Gene expression assessed by qPCR is expressed as fold-change " $x$ " compared to sham-operated controls at the same time point (i.e., $2^{-\Delta \Delta C t}$ ). Only changes greater than $1.5 x$ (or less than $1 / 2 x$ ) are shown. ${ }^{*} p<0.05$, 2-way ANOVA, Tukey HSD (except where noted). Analyses performed on $2^{-\Delta C t}$ values of injured vs. sham at designated times after TBI (shown as fold-change rounded to the nearest $1 / 2 x)$. ๆ $p<0.05$, 1-way ANOVA with all shams combined as time zero. $[x]$ brackets indicate changes $\geq 1.5$-fold that were not statistically significant, but showed a trend $(0.05<p<0.10)$. ${ }^{b}$ Below the limit of quantification at these times. Control (naïve, sham) values at or below limit of quantification, thus fold-change estimated based on highest control value(s).

(not shown). Heaviest staining appeared in layer II cortical neurons, Ammon's horn and dentate gyrus hippocampal neurons (Figure 1C), with many light to moderately stained cells in deeper cortical layers. Ipsilaterally, deep cortex and the hippocampal CA1 field showed a large number of lightly stained small cells (likely microglia or macrophages) that were not present contralaterally. In the midbrain, light staining was observed in some neuron-like and smaller cells, and in some microvascular and blood cells throughout the brain.

A different pattern of staining was observed for Cyp27a1 mRNA. Cingulate, parietal, perirhinal and piriform cortex showed Cyp27a1 stained cells throughout all cortical layers. Intense staining was observed in many cortical layer II and deeper layer neurons (Figure 2A, B), as well as Ammon's horn and dentate gyrus hippocampal neurons (Figure 2B). Medial habenula and some thalamic neurons were also intensely stained; and choroid plexus, third ventricle ependymal cells, and pial cells were moderately to intensely stained for Cyp27a1 mRNA (not shown). Moderate stain was seen in some larger vascular profiles (but not microvasculature), as well as many (possibly oligodendroglial) cells in the corpus callosum, hippocampal fimbria, and other white matter structures (Figure 2B).

\section{Discussion}

The parietal cortex and hippocampus are two brain regions that have been closely associated with the neurologic deficits observed in this model and in human brain injuries. Dynamic changes in mRNA levels were observed in these regions ipsilateral to TBI for many Cyp arachidonate monoxygenases and eicosanoid-related genes. A number of Cyp genes with other activities showed changes over time postinjury, as well. Altered mRNA levels do not unequivocally indicate altered enzymatic activities, however, nearly all changes showed higher mRNA levels, supporting their proposed function in the sustained surge 
of free fatty acid metabolism proximal to the site of injury during the hours and days after TBI. Altered eicosanoid metabolism at specific times after brain injuries contributes to dynamic local changes in the cerebral vasculature, inflammatory status, neural cell death, as well as neurophysiologic functions. It is not clear whether the observed responses to TBI are beneficial or not, but these results suggest brain region-specific changes in arachidonate metabolism due to alterations in the enzymatic machinery available at the time.

Histochemical detection of two Cyp mRNAs, one known to metabolize ArA (Cyp2j4) and the other known to metabolize cholesterol and vitamin D (Cyp27a1) showed different expression patterns at a time when both were induced in the injured brain. The distribution of Cyp2j4 expression appeared to increase predominantly in cortical layer II neurons ipsilateral to injury, whereas Cyp27a1 appeared more widespread in neurons and other cells throughout the brain. Staining for Cyp27a1 was seen in many non-neuronal cells, particularly in lining cells of the brain and less intensely in white matter and larger vascular structures. Less non-neuronal staining was seen for Cyp27a1, in some smaller (likely glial) cells in deep cortex and hippocampus ipsitlateral to injury, as well as light staining in some microvascular structures.

The catalytic specificity of many Cyp monoxygenases show promiscuous substrate specificity (e.g., ArA, linoleic acid [56,59], etc.) and varying product profiles. This may have a number of implications after TBI, since CSF levels of many free fatty acids are elevated [38]. One Cyp enzyme may metabolize the same substrate differently in different tissues or under different conditions, thus, Cyp activities remain poorly defined. Still it may be useful to organize the observed changes in terms of the expected activities of the eicosanoid-related genes in the injured brain (assuming increased mRNA levels yield increases in active proteins).

\section{Functionality of temporally regulated genes}

Early increases of prostanoid levels due to the ratelimiting enzyme COX2 in the injured brain, and their contribution to secondary injury has been well established $[39,41-43,45,47,48,51,60-69]$. This study revealed temporal regulation of prostanoid synthases, Ptgs1 (COX1), Ptgs2 (COX2), Ptges (PGE2 synthase, PGES), Ptgds2 (PGD2 synthase-2), Ptgis (prostacyclin synthase), and Tbxas1 (thromboxane A synthase 1) in hippocampus and cortex after TBI. In the cortex, Ptgs2, Ptges and Ptgis were acutely upregulated. Interestingly, Ptgds 2 and Ptgs 1 were elevated between 3 to $7 \mathrm{~d}$ postinjury. Another picture emerged in the hippocampus. Whereas Ptgs 2 and Ptgds 2 were upregulated as in cortex, Ptges and Ptgis were upregulated much later in hippocampus, at $7 \mathrm{~d}$ postinjury. The acute elevation in COX2 mRNA was consistent with previous results in the rat, where levels in hippocampus were greater than in cortex and COX2 mRNA returned to sham levels by $24 \mathrm{~h}$ postinjury [47,70]. Ptges is a prostaglandin (PG) synthase that catalyzes the formation of PGE2 from PGG2/PGH2 formed by cyclooxygenases. Its acute induction in the cortex was followed at $7 \mathrm{~d}$ by an increase in hippocampus. The levels of PGE2 itself are elevated acutely after TBI in both the parietal cortex and hippocampus, and remain elevated for at least $3 \mathrm{~d}$ postinjury [71], despite the increase in Hpgd mRNA (a prostaglandin dehydrogenase that converts PGs to their 15-keto metabolites) in hippocampus at $24 \mathrm{~h}$ postinjury. Contradictory to the finding of increased hippocampal Ptges at $7 \mathrm{~d}$, both tissue extraction [51,71] and hippocampal microdialysis studies [71] indicated a diminution of PGE2 levels at 6 to 7 days postinjury below that of sham animals. This increase may, therefore, represent a compensatory mechanism to return hippocampal PGE2 levels to steady state.

Thromboxane has been proposed to mediate hemostasis early after TBI by constricting blood vessels and promoting platelet activation and aggregation in damaged tissues $[41,42,72,73]$. Acute regulation of Tbxas 1 was not observed, either because it was transiently regulated before the initial $6 \mathrm{~h}$ time point, or possibly due to posttranscriptional regulation of this activity [74]. Unexpectedly, Tbxas 1 mRNA was elevated in ipsilateral hippocampus between 3 to $7 \mathrm{~d}$ postinjury (with sustained non-significant rises in cortex). Except for Tbxas1, these enzymes have been associated with vasodilatory activities. The results suggest a dynamic balancing of cerebral vasodilatation and vasoconstriction proximal to the site of injury after TBI. Moreover, late expression of Tbxas1 might have implications for astrocyte and microglial migration $[75,76]$ or remyelination [77] in the injured brain.

Four of the eight prostanoid receptor genes examined had altered expression levels after TBI (Table 1B). The prostacyclin receptor Ptgir mRNA levels in both hippocampus and cortex appeared to rise acutely, in parallel with Ptgis in parietal cortex. In contrast, the PGD2 receptor Ptgdr mRNA was elevated at $7 \mathrm{~d}$ in the hippocampus, while Ptgds2 levels in both cortex and hippocampus were upregulated from 3 to $7 \mathrm{~d}$ postinjury. In hippocampus, the prostaglandin receptor EP2 (Ptger2) was upregulated in what appeared to be a biphasic manner at $6 \mathrm{~h}$ and $3 \mathrm{~d}$ postinjury. The prostaglandin receptor EP4 (Ptger4) was upregulated as well, from 3 to $7 \mathrm{~d}$ in the hippocampus and throughout the time course in parietal cortex. Both these genes have been associated with the vasoactivity of PGE2, but also have been implicated in potential neuroprotective [78] and antiinflammatory $[79,80]$ activities in the brain.

Early postinjury there was an upregulation in lipoxygenase-associated gene expression (Alox15, Alox5ap) in the cortex. Only Alox5ap mRNA was elevated in 


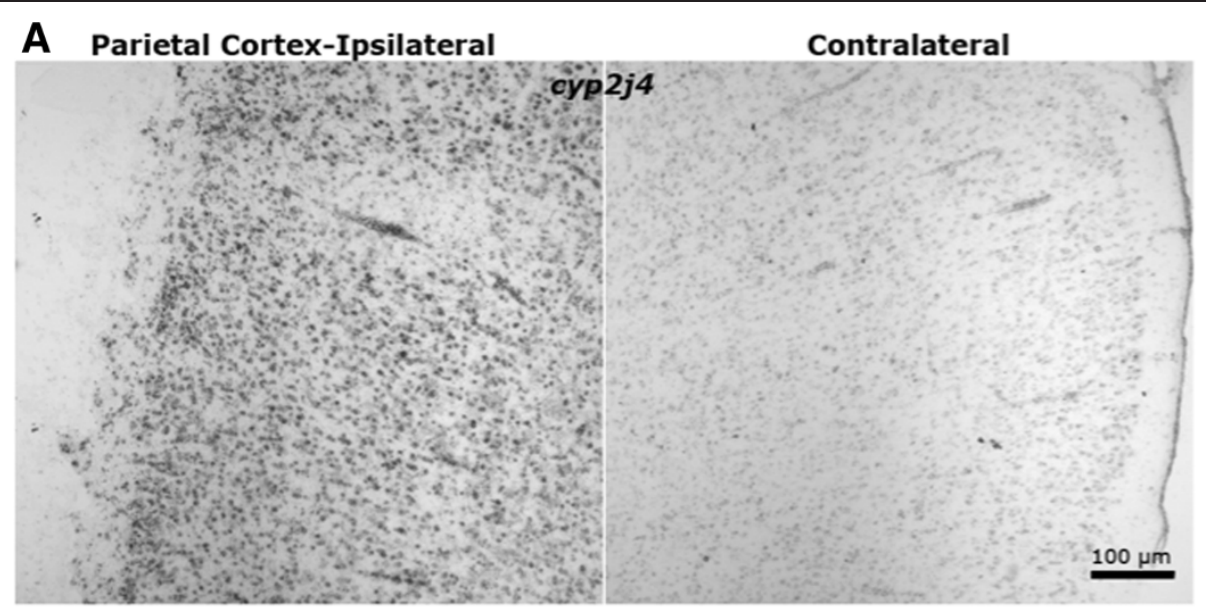

\section{B Piriform Cortex-Ipsilateral}

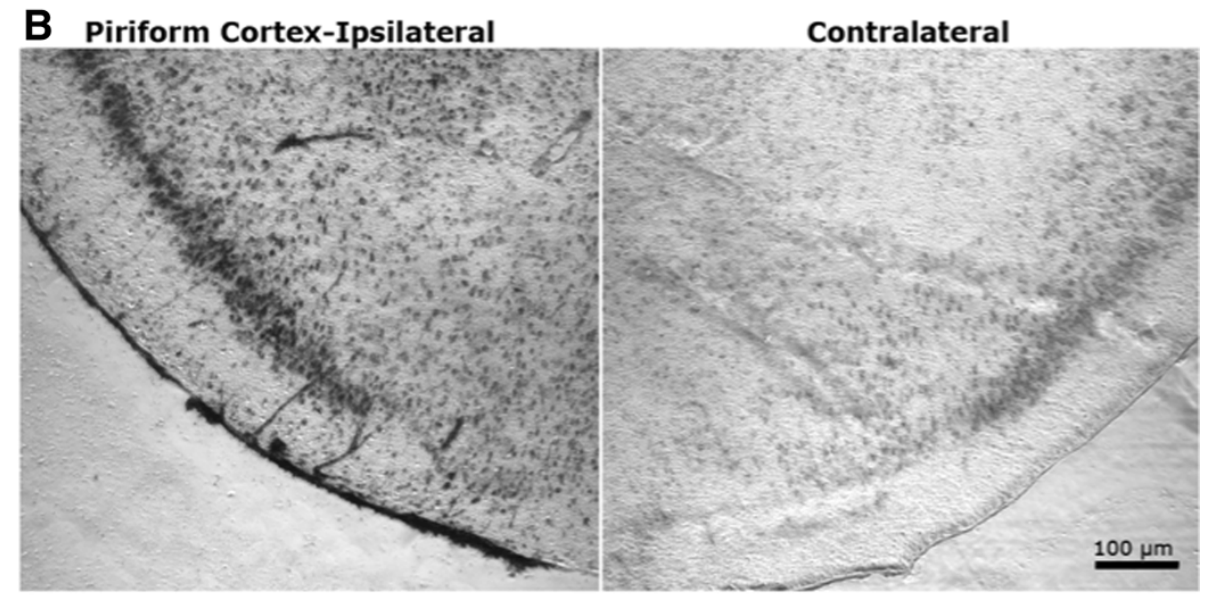

C

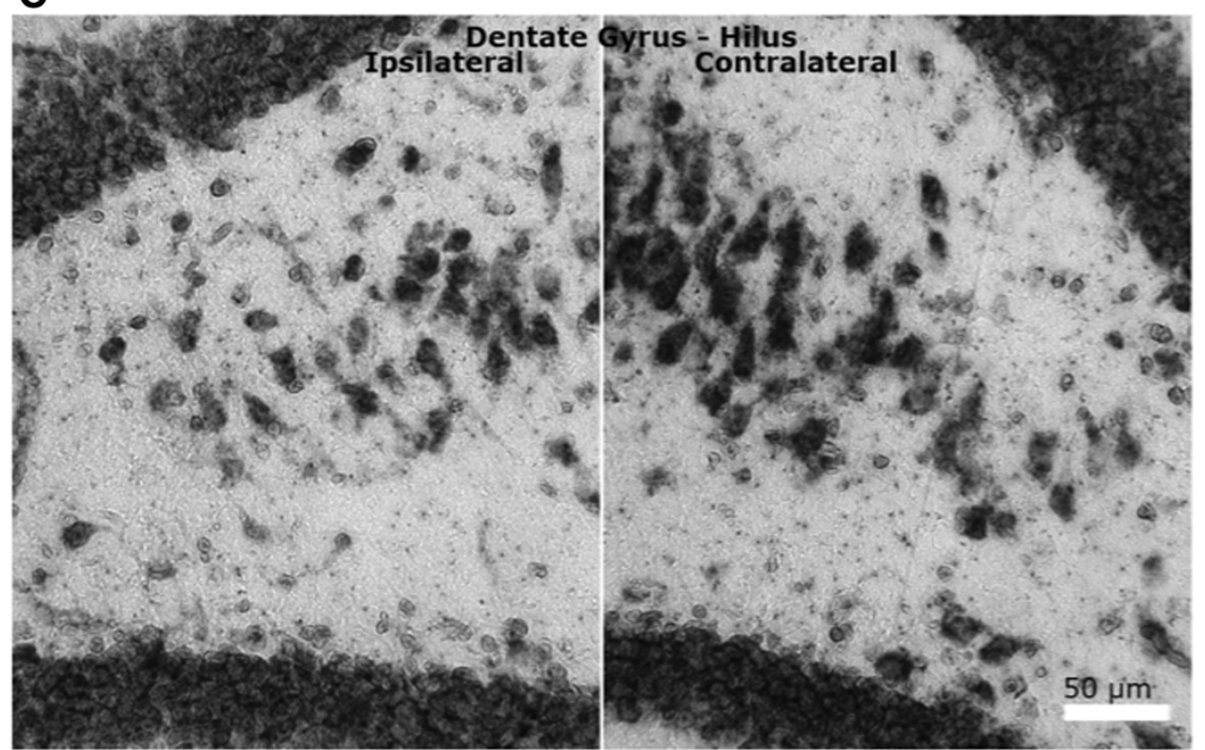

Figure 1 In situ hybridization histochemistry for rat Cyp2j4 mRNA in brain 7 days after TBI. Representative fields of injured and contralateral (A) parietal cortex; (B) piriform cortex; (C) hippocampal dentate gyrus. Note the apparent loss of pyramidal neurons in the ipsilateral dentate hilar region. Little staining was observed in the corpus callosum or other white matter structures. Some microvascular profiles appeared to stain positive in these non-perfused fresh frozen brain sections. Studies were carried out starting anterior to the site of injury, staining every sixth section through the injured volume (bregma $-1.8 \mathrm{~mm}$ to approximately $-4.5 \mathrm{~mm}$, according to the coordinates of Paxinos and Watson [155]). High stringency hybridization and washes were performed as described in Section In situ hybridization histochemistry. 


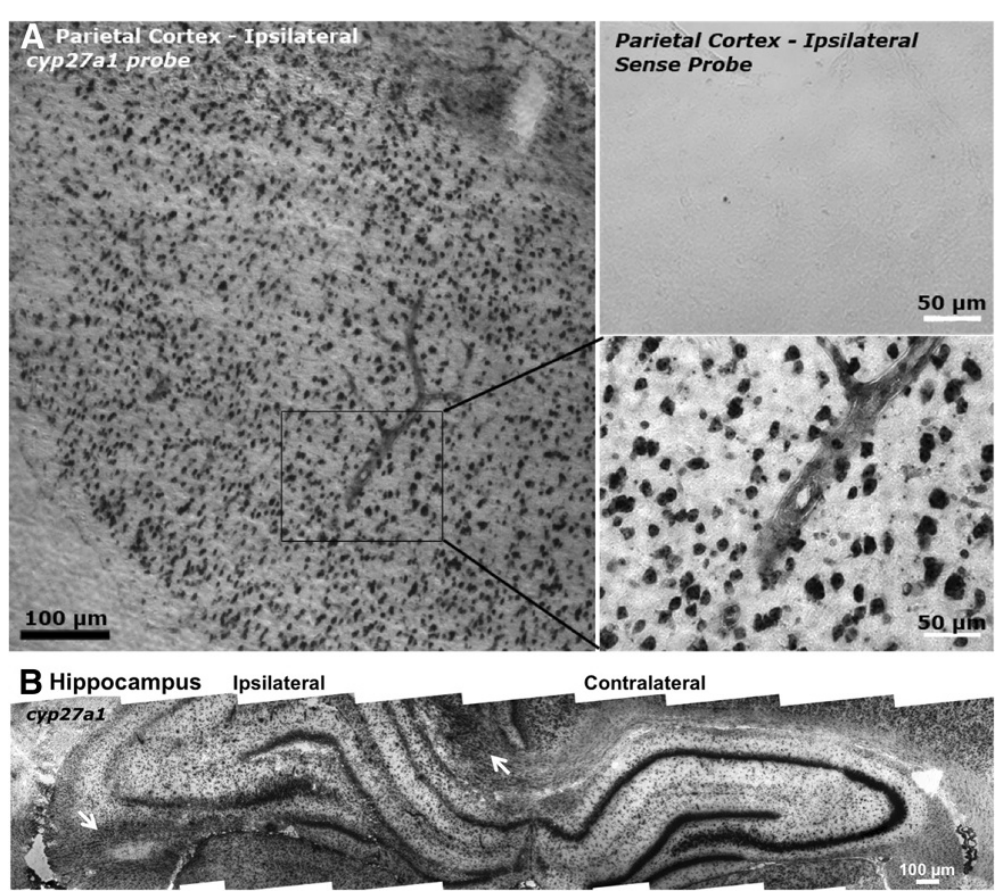

Figure 2 In situ hybridization histochemistry for rat Cyp27a1 mRNA in brain 7 days after TBI. (A) Representative fields of injured parietal cortex with higher magnification of negative control sense probe in the same region of a different section (top inset) and neuronal staining with a large vascular profile (bottom inset). (B) Composite showing injured and contralateral hippocampal Cyp27a1 mRNA with ablation of neuronal staining, as well as heavier non-neuronal staining ipsilateral to injury. Some intense white matter staining is visible medially in the corpus callosum and the ipsilateral hippocampal fimbria (arrows). See Figure 1 legend for methodologic details.

hippocampus, from 3 to 7d postinjury. Leukotriene products are known to promote neuroinflammation, increased vascular permeability, and edema [81-83]; but may also be associated with the production of potentially neuroprotective HETEs [84,85]. However, unlike formation of 12-HETE by Cyps, the 12-lipoxygenase pathway produces potentially neurotoxic HPETE intermediates [86]. Perhaps in response, several Cyps that metabolize leukotrienes (Cyp4f18 at $6 \mathrm{~h}$ only, Cyp4f5 and Cyp4f6 at 3 to $7 \mathrm{~d}$, see below) as well as the leukotriene hydrolase Lta4h (at $3 \mathrm{~d}$ postinjury) appeared to be upregulated in the cortex. Protein levels of Lta $4 h$ have only recently been characterized in the brain [87].

Of the sixty-five Cyp genes assayed, sixteen arachidonatemetabolizing Cyps (Table 1A) and twelve other Cyps (Table $1 C$ ) were regulated in the injured brain regions examined. In the hippocampus at $6 \mathrm{~h}$ after TBI, Cyp2c6, Cyp2c22, Cyp2c23, Cyp2e1, and Cyp4a1 mRNAs were elevated (as was Cyp2c54, a mouse gene homolgous to rat Cyp2c's, see Results). The increased levels of Cyp2c22, Cyp2c23, and perhaps Cyp2c54 (homologous to human Cyp2c8 and $C y p 2 c 9$ ) represent activities that synthesize various EETs [88-90], with predominantly vasodilatory activity [91-93]. Except for Cyp4a1, these enzymes have been associated with hypertension; namely, depletion of these activities appears to result in vasoconstriction and increased blood pressure [94-96].

An arachidonate $\omega$-hydroxylase, Cyp4a1 likely produces 20-HETE as its main product [97-99] (it also catalyzes $\omega-1$ hydroxylation of fatty acids, $\omega$-hydroxylation of prostaglandins [97]). In addition, hippocampal levels of Cyp4a8, also associated with 20-HETE formation [100], were elevated throughout the time course studied. Thus, Cyp4a1 and Cyp4a8 stand out as acute and chronic vasoconstrictive activities, respectively, particularly after brain injuries [7,9,100-103].

At later times postinjury, hippocampal Cyp2j3, Cyp2j4, Cyp2u1, Cyp4f5, and Cyp4f6 levels were elevated. Cyp2j3 and Cyp2j4 likely produce mainly EETs [52,92,104]. Cyp2u1 catalyzes predominantly 19- and 20-HETE formation [105], whereas the Cyp4f5 and Cyp4f6 hydroxylases appear to inactivate leukotrienes [50,106,107]. As with the prostanoid synthases, it appears that regulation of both vasodilatory and vasoconstrictive Cyp activities may be required to balance the circulatory needs of the injured hippocampus.

In the cortex, only two Cyp arachidonate monoxygenases were acutely upregulated after TBI. At $6 \mathrm{~h}$, Cyp4f18, and from $6 \mathrm{~h}$ to $3 \mathrm{~d}$ postinjury Cyp $4 b 1 \mathrm{mRNA}$ levels were elevated. Both these genes have been 
associated with potentially neuroprotective activities. Cyp4f18 metabolizes proinflammatory leukotrienes [108] and Cyp $4 b 1$ has been implicated in 12-HETE synthesis in ocular tissues $[84,85,109]$. Hampson and Grimaldi [28] found that 12-HETE can protect neurons from glutamatemediated excitotoxicity in vitro. Interestingly, while elevated Cyp4b1 mRNA was seen at $6 \mathrm{~h}$ in the cortex, its elevation was delayed until $24 \mathrm{~h}$ postinjury in the hippocampus, a site of extensive apoptotic cell death [110-112].

Another conspicuous finding was the reduced mRNA level of Cyp4x1 in the cortex throughout the postinjury period. This gene is predominantly expressed in brain [113] and has recently been characterized in converting the endocannabinoid anandamide to a single monooxygenated product, 14,15-epoxyeicosatrienoic ethanolamide [114,115]. The observed reduction of this activity might contribute to endocannabinoid-mediated neuroprotection after TBI [116,117].

Several Cyps not directly associated with polyunsaturated fatty acid metabolism also showed time- and tissuedependent changes after TBI that might be relevant to secondary injury and recovery. Cyp27a1, the sterol 27hydroylase, was differentially expressed after TBI. Hippocampal Cyp27a1 mRNA levels increased 3- to 8-fold at $72 \mathrm{~h}$ to $168 \mathrm{~h}$ postinjury, respectively, whereas cortical levels did not appear to change. Histochemistry revealed cells intensely stained for Cyp27a1 mRNA throughout the cortex, deep brain structures, and meninges, choroid plexus and ependymal cells. Peripherally, this enzyme metabolizes bile acids, cholesterol and vitamin D3, and has been suggested to contribute to neurodegenerative disease by increasing cholesterol penetration across the blood brain barrier by conversion to 27-hydroxycholesterol [118]. Conversely, intrinsic brain expression of Cyp27a1 might enhance the egress of cholesterol, released from damaged cell membranes, from the brain to the peripheral circulation.

Two of the Cyps acutely induced in the brain after TBI have been shown to be regulated by acute stress-related stimuli (e.g., stress hormones, ethanol toxicity). For example, Cyp2c6 is rapidly induced by glucocorticoids in rat hepatoma cells [119], and is a close homolog of human Cyp $2 c 8$ and Cyp $2 c 9$ implicated in eicosanoid production [120-122]. Also acutely regulated, Cyp2e1 is a major ethanol-inducible gene in the liver and metabolizes arachidonic acid to HETEs [123]. Its expression is 1000-fold lower in the hippocampus than the liver, and is induced in neural cells by high concentrations of ethanol [124].

Surprisingly, Cyp2e1 inhibition has been shown to increase rat brain dopamine levels, implicating it in catecholamine biotransformation [125]. Selected members of the Cyp $2 d$ subfamily (Cyp2d2, $2 d 4$ or $2 d 18$ ) also have been shown to synthesize dopamine in vitro and in vivo
$[126,127]$, although none of these genes were regulated in hippocampus or cortex after TBI. Dopamine levels decrease acutely in the traumatically injured rat cortex, but showed increased levels in hypothalamus and striatum as soon as $1 \mathrm{~h}$ or $6 \mathrm{~h}$ postinjury, respectively [128]. These regional changes might reflect regional decreases in Cyp2e1 expression, or increased Cyp $2 d$ activity. Further study of hypothalamic and striatal gene expression may clarify the contribution of Cyps to acute dopamine fluxes after TBI.

In addition to its possible role in EET production, Cyp2c22 is both regulated by and able to metabolize alltrans retinoic acid [90]. Its acute regulation after TBI suggests the possibility of transducing cross-lipid signalling, perhaps with respect to neuroinflammatory cell proliferation [90]. In addition, Cyp26b1 metabolizes retinoic acid, including "all trans" retinoic acid, a process thought to contribute to regulation of spatial patterning during neurogenesis [129-131] and neuroplasticity [132,133]. Induced in both cortex and hippocampus at $7 \mathrm{~d}$ postinjury, this enzyme might contribute to neuroplasticity in the injured brain, possibly in the formation of neuronalastroglial boundaries.

TBI-mediated regulation of Cyp17a1 was observed only in the hippocampus, being elevated at the $24 \mathrm{~h}$ time point. Cyp17a1, the steroid 17alpha-hydroxylase/17,20lyase, is one of the key enzymes in glucocorticoid, dehydroepiandrosterone, and androgen biosynthesis [134]. Its activity in the brain, until fairly recently a matter of debate, has been established [135-137]. This activity is known to metabolize progesterone, a neuroprotective neurosteroid [138-140] now in phase III clinical trials for treatment of TBI $[141,142]$. This is also a critical step in the biosynthesis of other potentially neuroprotective neurosteroids, including dehydroepiandrosterone [70,143,144], testosterone $[145,146]$, and estradiol [147-150]. It remains to be determined whether the enhancement of this activity (or the others described above) after brain injury would improve the recovery phenotype.

Tissue-specific differences between cortex and hippocampus were observed in basal mRNA levels in over half the genes examined. In addition, hippocampus and cortex responded differently in most cases of injury-induced changes, as well. Nonetheless, nine genes were coordinately regulated, increasing approximately the same extent, at similar time points in both tissues. These were Alox5ap, Cyp2j4, Cyp26b1, Pla2g4a, Ptgir, Ptgs1, Ptgs2, Ptgds, and Tbxas1. This might be attributable to release of factors into the blood or CSF, or neurotransmitter-mediated induction of these genes in multiple brain regions. Global changes were also observed in comparing naïve and sham-operated animals in a number of genes (Additional file 1: Table S3), suggesting that anesthesia and/or craniotomy induced global, sometimes lasting changes in the brain. 


\section{Conclusion}

This qPCR study has established detectable mRNA levels for several Cyps not previously described in the brain (see Additional file 1: Table S1 for genes detected in cortex and hippocampus). This suggests the presence of these activities, despite any lack of change postinjury. There will be, going forward, a need for further study to better understand these results. For example, only changes greater than $50 \%$ in parietal cortex or hippocampus were analyzed in this study due to the large number of genes examined. Based on these mRNA and limited histochemical results, it would be of interest to determine the regulation of these Cyp and eicosanoidrelated genes in more distal brain regions, e.g., hypothalamus, dorsolateral thalamus, piriform cortex or amygdala, where neurologic dysfunction might also impact brain injury recovery. These and more subtle changes in gene expression, and in other brain regions, likely contribute to the overall maintenance of lipid metabolism in the healthy brain, and have implications for neural changes in arachidonate metabolism in response to injury.

The dynamic environment in the brain after traumatic injury likely requires different metabolic events at different times for optimal repair to proceed. It may be speculated that timely regulation of arachidonic acid metabolism contributes to functional recovery after TBI. To determine whether these eicosanoid-related changes in gene expression are adaptive or pathologic, pharmacologic and/or genetic manipulation of each gene (product) will need to be performed at a given time after brain injury. Thus, the investigation of arachidonic acid metabolism in the brain continues to be a fertile field of investigation.

\section{Methods}

Traumatic brain injury

All animal protocols used were approved by the University of Cincinnati IACUC. The lateral cortical contusion rat TBI model was carried out as previously described [47] with minor modifications. Sprague-Dawley rats, (male, 300-400 g Harlan) were pre-anaesthetised with isoflurane and maintained at a surgical level of anaesthesia with a facemask using oxygen and isoflurane. After immobilisation in a stereotaxic device, a $6 \mathrm{~mm}$ craniotomy was performed over the parietal cortex between the left lateral ridge and the sagittal suture, midway between lambda and bregma. Animals were randomly assigned to sham or injury groups. Traumatic brain injury was induced via a cortical contusion using a pneumatic piston $(5 \mathrm{~mm}$ diameter, $4 \mathrm{~m} / \mathrm{s}, 100 \mathrm{~ms}$ ) to a depth of $2.7 \mathrm{~mm}$. Sham operated controls were surgically prepared but not injured. Postsurgical neurological assessments were performed just after removing aneasthesia for exclusion criteria.

\section{Sample preparation}

Conscious animals were decapitated using a sharpened guillotine at preselected times of 6, 24, 72 and 168 hours $(\mathrm{n}=4$ per injured time point, $\mathrm{n}=3$ per sham time point, $\mathrm{n}=4$ naïves). Brain regions were rapidly dissected on ice and flash frozen on powdered dry ice. Tissue samples were stored at $-80^{\circ} \mathrm{C}$ until RNA extraction. Ipsilateral parietal cortex, $\sim 100 \mathrm{mg}$, not including the site of injury was used; for hippocampus, the entire ipsilateral structure was used. Total RNA was isolated by sonicating frozen tissue in TRI reagent (Molecular Research Labs, Cincinnati, $\mathrm{OH}$ ), following the protocol through chloroform extraction. Aqueous phase was dissolved in RNA lysis buffer (RNeasy kit, Qiagen, Chatsworth, CA), and RNA purified according to kit protocol, including oncolumn DNase. RNA quality was assessed by spectrometry, microfluidics and denaturing gel electrophoresis.

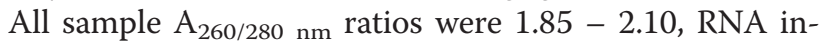
tegrity numbers of $6.5 \pm 0.5$ were obtained (Total RNA Nano Series II, Agilent), and ribosomal RNAs comprised $21.2 \pm 3.8 \%$ of total RNA (mean \pm SD of all samples).

A high capacity cDNA reverse transcription kit (random hexamer primers, $\mathrm{ABI}$ ) was used to generate cDNA from total RNA $\left(2 \mu \mathrm{g}, 2 \mathrm{~h}, 37^{\circ} \mathrm{C}\right)$; duplicate reactions provided enough template for all assays. Aliquots of each sample cDNA were stored at $-80^{\circ} \mathrm{C}$.

\section{Real-time PCR}

Quantitative real-time polymerase chain reaction (qPCR) studies were carried out in conformity with recommended guidelines [151]. Sample cDNAs were combined with $2 \times$ Universal PCR Master Mix (ABI, Applied Biosystems, Inc., Foster City, $\mathrm{CA}$ ) in a custom 96 well plate array (ABI, see Additional file 1 for details) using an ABI PRISM 7500 system (courtesy of Allyson Cole Strauss in the lab of Prof. Jack Lipton, U. Cincinnati Department of Psychiatry). Each TaqMan ${ }^{\circ}$ Gene Expression Assay (ABI) consisted of two sequence-specific PCR primers and a TaqMan assayFAM $^{\text {six }}$ dye-labeled MGB probe. A quantity of $60 \mathrm{ng}$ cDNA in a $20 \mu \mathrm{L}$ reaction was chosen because in cortex, $96 \%$ of the probe sets (in hippocampus, $84 \%$ ) fell within the dynamic range after 40 cycles of PCR.

Initially, 8 cDNA samples were evaluated in triplicate and the interassay variance was found to be very small (coefficients of variation less than 3\% for all assays). Thereafter, $3-4$ biological replicates were assayed using one technical replicate. Acrylamide gel analyses of these reactions showed appropriately sized amplicon bands throughout, and "no reverse transcriptase" controls showed no bands. Assays with very low abundance targets $\mathrm{C}_{\mathrm{t}}>37.4$ ( $4 \%$ of cortex samples, $15 \%$ of hipocampal samples) were judged not abundant enough for precise quantification and were assigned an expression value of zero. 
Consistent reaction efficiencies were confirmed for relative quantification using a reference gene [152]. Serial dilutions of the initial 8 sample cDNAs were assayed on the custom plate arrays. When $C_{t}$ was graphed against log cDNA input for each assay and dilution, the mean slope was $-2.80 \pm 0.04$ (ideal slope $=-3.32$ [152]), indicating low variability and high amplification efficiencies throughout the assays. Efficiencies of very low abundance genes (undiluted $C_{t} \geq 35.9$ ) could not be evaluated by this method, however, because serial dilution brought $C_{t}$ values below the range of detection. Further validation was carried out by graphing $\Delta C_{t}$ versus log cDNA input [153], yielding absolute value slopes less than $0.1(0.08 \pm 0.02$, excluding the very low abundance assays).

\section{Data analysis}

Results from qPCR were calculated from $C_{t}$ values (the estimated number of PCR cycles to reach the threshold fluorophore release, when signal $>10$ standard deviations of fluoresence background, indicating entry into the exponential phase of amplification, ABI 7500 manual) generated for each probe set. Gene expression is most often represented as a normalized value, i.e., with respect to an invariant housekeeping gene, sample protein, or tissue weight. For profiling the large number of genes in this study, we used a normalized representation of the target $(i)$ to reference (ref) gene copy number ratio based on the exponential of $\Delta \mathrm{C}_{\mathrm{t}}=\left(\mathrm{C}_{\mathrm{t} i}-\mathrm{C}_{\mathrm{tref}}\right)[153,154]$. The number of cycles, $C_{t}$ is related to the initial copy number of cDNA $\left(\mathrm{N}_{0}\right)$ in the sample by the equation $\mathrm{N}_{0 i}=\mathrm{k}_{i}\left(1+\mathrm{E}_{i}\right)^{-\mathrm{Ct} i}$, where $\mathrm{k}_{i}$ is a constant that directly relates $\mathrm{N}_{0 i}$ to copy number, and $\mathrm{E}_{i}$ is the efficiency of the PCR amplification, ranging between 0 and 1 . Dividing $\mathrm{N}_{0 i} / \mathrm{N}_{\text {Oref }}$ yields a constant, $\mathrm{K}_{i}=\mathrm{k}_{i} / \mathrm{k}_{\text {ref }}$, that depends on the individual properties of each probe set [153]. When the target efficiency and reference efficiency are comparable (within about $10 \%$ of each other [154], see above) they can be assumed to be equal, and the initial copy number ratio $f_{\mathrm{i}}=\mathrm{N}_{0 i} / \mathrm{N}_{\text {Oref }}=K_{i} 2^{-\Delta \mathrm{Ct}}$. Since $\mathrm{K}_{i}$ is a constant for each probe set, $2^{-\Delta \mathrm{Ct}}$ is directly proportional to the ratio of target to reference initial copy number for each sample and assay, and can be treated as a continuous variable, amenable to standard statistical approaches $[152,154]$. The $2^{-\Delta C t}$ values were evaluated by two-way ANOVA (independent variables: treatment, time) with Tukey HSD post-hoc tests. A separate one-way ANOVA was performed with all shams combined. A p-value less than 0.05 was required to reject the null hypothesis that group means were equivalent. For presentation purposes in Table 1 ( $n$-fold mRNA levels), the mean $2^{-\Delta C t}$ values from injured tissue were normalized to shams at the same time point.

\section{In situ hybridization histochemistry}

Cellular localization of eicosanoid-related gene expression was carried out on $20 \mu \mathrm{m}$ sections of fresh frozen brain tissue by in situ hybridization histochemistry utilizing internally labeled complementary RNA probes. Sections from injured and sham-operated rat brains $(n=3$ each, $7 d$ postinjury) were chosen starting anterior to the site of injury and then every sixth section through the injured volume (Bregma $-1.8 \mathrm{~mm}$ to approximately $-4.5 \mathrm{~mm}$, according to the coordinates of Paxinos and Watson [155]). Sequences unique for the individual Cyp genes (as determined by BLAST analyses) were derived from the 3'-end of the coding region and a portion of the untranslated region, spanning a putative exon-exon splice junction. These sequences were amplified by high fidelity PCR (Roche Applied Science, Penzberg, Germany) from rat brain cDNA and cloned into pGEM (Promega, Madison, WI) vectors. For rat Cyp2j4, the insert included nucleotides 1188 to 1585 (NM_023025); for rat Cyp27a1, the insert included nucleotides 1361 to 1766 (NM_178847), both with respect to the translation initiation start site. Plasmids were linearized to provide a template for RNA synthesis directed by a viral T7 or SP6 promoter to produce either antisense or sense (negative control) probes. RNA was synthesized according the the manufacturer's instructions (Roche digoxigenin labeling kit), template DNA degraded (RQ1 ribonuclease-free DNase, Promega) and RNA probes purified on spun columns (Qiagen, Chatsworth, CA). All probes were size analyzed on denaturing $6 \%$ polyacrylamide-urea gels. Probe concentration and quality were assessed by absorbance at $260 \mathrm{~nm}\left(\mathrm{~A}_{260}\right)$ and the $\mathrm{A}_{260} / \mathrm{A}_{280}$ ratio. Studies for each probe (and controls) were carried out in parallel with equal mass of probe, hybridization and development times. Prehybridization and hybridization were carried out in 50\% formamide, essentially as described [156], with 400 $\mathrm{ng} / \mathrm{mL}$ RNA probes under high stringency conditions to minimize cross-reactivity between the target genes and closely related Cyp family members. Overnight incubation was at $50^{\circ} \mathrm{C}$ in a humidified chamber. All washes were $15 \mathrm{~min}$ at $50^{\circ} \mathrm{C}$ : twice in $2 \mathrm{xSSC}$ (SSC is $150 \mathrm{mM}$ sodium chloride, $15 \mathrm{mM}$ sodium citrate, $\mathrm{pH} 7.4$ ), twice in $1 \mathrm{xSSC}$, twice in $0.1 \mathrm{xSSC}$. Staining was performed exactly as described (DIG Wash \& Block Buffer Set, DIG Staining Solution, Roche) by incubating sections with wash buffer, blocking reagent, then alkaline phosphatase-conjugated anti-digoxigenin $\mathrm{F}_{\mathrm{ab}}$ fragments (1:250, $1 \mathrm{~h}$ in a humidified chamber at room temperature), washing twice and developing the color overnight at room temperature in the presence of $1 \mathrm{mM}$ levamisole (Sigma, St. Louis, MO) to inhibit endogenous phosphatase activity. Sections were washed (50 mM tris, $5 \mathrm{mM}$ EDTA, pH7.4), rinsed in distilled water, dehydrated in increasing ethanol washes, and coverslipped with Permount (Fisher Scientific) for observation under bright field microscopy. 


\section{Additional files}

Additional file 1: Table S1. Detection of mRNA in naïve, sham, and injured hippocampus $(\mathrm{HCl})$ or cortex $(\mathrm{CXI})$. Positive or negative $\mathrm{qPCR}$ assay detection is shown for each gene, along with the $A B I$ assay identification and a description of the gene. The $2^{-\Delta C t}$ for each of the assayed genes is shown in Tables S4 and S5. Table S2. Regional differences in mRNA levels in naïve and sham brains. Combined data from naïves and shams are compared to show distinct levels of mRNA expression between ipsilateral parietal cortex and hippocampus. Table S3. Sham effects on mRNA levels in naïve and sham brains. Comparison of gene expression in naïves and shams at different times postsurgery showed a number of sham effects, evaluated by 1-way ANOVA with naives at time 0 , and shams at 6 h, 24 h, 72 h, and 168 h. $p<0.05$, ANOVA Tukey HSD, except where bracketed, $0.05<p<0.10$. Table S4. Mean and standard error expression values for ispilateral hippocampus ( $n=3-4$ for each). Table S5. Mean and standard error expression values for ispilateral parietal cortex ( $n=3-4$ for each).

Additional file 2: Figure S1. Graph of $C_{t}$ values from three "housekeeping" genes assayed by qPCR in parietal cortex. A total of 29 animals were assessed, with $n=4$ naïves (time 0 ), $n=3$ shams per time point, and $n=4$ injured per time point. One Gapdh point $\left(C_{t}=39.4,72 \mathrm{~h}\right.$ sham) was removed as an outlier. The least variant of these genes over the entire data set was Ppia (cyclophilin A), that was used for normalization of all subsequent data.

\section{Additional file 3: Cross species control sequence comparisons} between mouse and rat Cyps.

Additional file 4: Figure S2. Induction of Cyp $4 b 1$ mRNA in injured parietal cortex and hippocampus after brain injury. Acutely after TBI, Cyp4b1 was elevated in ipsilateral parietal cortex (CXI) and remained elevated for at least $3 d$ postinjury compared to shams. In ipsilateral hippocampus $(\mathrm{HCl})$, several-fold elevations occurred starting $24 \mathrm{~h}$ and continued for at least $7 d$ postinjury. Dotted lines represent mean naïve mRNA levels $(n=4) ; n=3$ shams and $n=4$ injured per time point. ${ }^{*} p<0.05,2$-way ANOVA, Tukey HSD vs. shams at same time point. १p $<0.05,1$-way ANOVA, Tukey HSD, with shams combined at time zero.

\section{Competing interests}

The authors have no competing interests.

\section{Authors' contributions}

KIS designed the study, performed the statistical analyses and drafted the manuscript. RC participated in the design of the study and determined the sequence specificity of the probes and assisted in the sequence selections. $M B$ and RM determined the specificity of the ABI probe sets, carried out the qPCR genomic studies, and participated in molecular cloning. All authors approved the final manuscript.

\section{Acknowledgements}

This work was supported by NINDS R01-NS054890. The authors express their appreciation for excellent technical assistance from Nathan Kuhn, Jason Dudley, Andrew Barnikow, and Allyson Cole-Strauss.

Received: 1 October 2012 Accepted: 16 April 2013

Published: 4 May 2013

\section{References}

1. Nelson DR, Zeldin DC, Hoffman SM, Maltais LJ, Wain HM, Nebert DW: Comparison of cytochrome P450 (CYP) genes from the mouse and human genomes, including nomenclature recommendations for genes, pseudogenes and alternative-splice variants. Pharmacogenetics 2004, 14(1):1-18.

2. Kozak W, Kluger MJ, Kozak A, Wachulec M, Dokladny K: Role of cytochrome P-450 in endogenous antipyresis. Am J Physiol Regul Integr Comp Physiol 2000, 279(2):R455-R460.

3. McGiff JC, Carroll MA: Cytochrome P450-dependent arachidonate metabolites, renal function and blood pressure regulation. Adv Prostaglandin Thromboxane Leukot Res 1991, 21B:675-682.
4. Makita K, Falck JR, Capdevila JH: Cytochrome P450, the arachidonic acid cascade, and hypertension: new vistas for an old enzyme system. FASEB J 1996, 10(13):1456-1463.

5. Fitzpatrick FA, Murphy RC: Cytochrome $\mathbf{P}-450$ metabolism of arachidonic acid: formation and biological actions of "epoxygenase"-derived eicosanoids. Pharmacol Rev 1988, 40(4):229-241.

6. Harder DR, Gebremedhin D, Narayanan J, Jefcoat C, Falck JR, Campbell WB, Roman R: Formation and action of a P-450 4A metabolite of arachidonic acid in cat cerebral microvessels. Am J Physiol 1994, 266(5 Pt 2):H2098-H2107.

7. Gebremedhin D, Lange AR, Lowry TF, Taheri MR, Birks EK, Hudetz AG, Narayanan J, Falck JR, Okamoto H, Roman RJ, et al: Production of 20-HETE and its role in autoregulation of cerebral blood flow. Circ Res 2000, 87(1):60-65.

8. Yu M, Cambj-Sapunar L, Kehl F, Maier KG, Takeuchi K, Miyata N, Ishimoto T, Reddy LM, Falck JR, Gebremedhin D, et al: Effects of a 20-HETE antagonist and agonists on cerebral vascular tone. Eur J Pharmacol 2004, 486(3):297-306

9. Poloyac SM, Zhang Y, Bies RR, Kochanek PM, Graham SH: Protective effect of the 20-HETE inhibitor HET0016 on brain damage after temporary focal ischemia. J Cereb Blood Flow Metab 2006, 26(12):1551-1561.

10. Imig JD, Simpkins AN, Renic M, Harder DR: Cytochrome P450 eicosanoids and cerebral vascular function. Expert Rev Mol Med 2011, 13:e7.

11. Ellis EF, Amruthesh SC, Police RJ, Yancey LM: Brain synthesis and cerebrovascular action of cytochrome P-450/monooxygenase metabolites of arachidonic acid. Adv Prostaglandin Thromboxane Leukot Res 1991, 21A:201-204.

12. Leffler CW, Fedinec AL: Newborn piglet cerebral microvascular responses to epoxyeicosatrienoic acids. Am J Physiol 1997, 273(1 Pt 2):H333-H338.

13. Peng X, Carhuapoma JR, Bhardwaj A, Alkayed NJ, Falck JR, Harder DR, Traystman RJ, Koehler RC: Suppression of cortical functional hyperemia to vibrissal stimulation in the rat by epoxygenase inhibitors. Am J Physiol Heart Circ Physiol 2002, 283(5):H2029-H2037.

14. Iliff JJ, Close LN, Selden NR, Alkayed NJ: A novel role for P450 eicosanoids in the neurogenic control of cerebral blood flow in the rat. Exp Physiol 2007, 92(4):653-658.

15. Zhang W, Otsuka T, Sugo N, Ardeshiri A, Alhadid YK, lliff JJ, DeBarber AE, Koop DR, Alkayed NJ: Soluble epoxide hydrolase gene deletion is protective against experimental cerebral ischemia. Stroke 2008, 39(7):2073-2078.

16. Campbell WB, Gebremedhin D, Pratt PF, Harder DR: Identification of epoxyeicosatrienoic acids as endothelium-derived hyperpolarizing factors. Circ Res 1996, 78(3):415-423.

17. Zou AP, Fleming JT, Falck JR, Jacobs ER, Gebremedhin D, Harder DR, Roman RJ: 20-HETE is an endogenous inhibitor of the large-conductance $\mathrm{Ca}(2+)$-activated K+ channel in renal arterioles. Am J Physiol 1996, 270(1 Pt 2):R228-R237.

18. Wu SN, Li HF, Chiang HT: Actions of epoxyeicosatrienoic acid on largeconductance $\mathrm{Ca}(2+)$-activated $\mathrm{K}(+)$ channels in pituitary $\mathrm{GH}(3)$ cells. Biochem Pharmacol 2000, 60(2):251-262

19. Qu W, Bradbury JA, Tsao CC, Maronpot R, Harry GJ, Parker CE, Davis LS, Breyer MD, Waalkes MP, Falck JR, et al: Cytochrome P450 CYP2J9, a new mouse arachidonic acid omega-1 hydroxylase predominantly expressed in brain. J Biol Chem 2001, 276(27):25467-25479.

20. Kroetz DL, Zeldin DC: Cytochrome P450 pathways of arachidonic acid metabolism. Curr Opin Lipidol 2002, 13(3):273-283.

21. Ferroni S, Valente $P$, Caprini M, Nobile M, Schubert $P$, Rapisarda C: Arachidonic acid activates an open rectifier potassium channel in cultured rat cortical astrocytes. J Neurosci Res 2003, 72(3):363-372.

22. Inceoglu B, Schmelzer KR, Morisseau C, Jinks SL, Hammock BD: Soluble epoxide hydrolase inhibition reveals novel biological functions of epoxyeicosatrienoic acids (EETs). Prostaglandins Other Lipid Mediat 2007, 82(1-4):42-49.

23. Iliff JJ, Fairbanks SL, Balkowiec A, Alkayed NJ: Epoxyeicosatrienoic acids are endogenous regulators of vasoactive neuropeptide release from trigeminal ganglion neurons. J Neurochem 2010, 115(6):1530-1542.

24. Higashimori $H$, Blanco VM, Tuniki VR, Falck JR, Filosa JA: Role of epoxyeicosatrienoic acids as autocrine metabolites in glutamatemediated $\mathrm{K}+$ signaling in perivascular astrocytes. Am J Physiol Cell Physiol 2010, 299(5):C1068-C1078.

25. Campbell WB: New role for epoxyeicosatrienoic acids as antiinflammatory mediators. Trends Pharmacol Sci 2000, 21(4):125-127.

26. Chen JK, Capdevila J, Harris RC: Cytochrome p450 epoxygenase metabolism of arachidonic acid inhibits apoptosis. Mol Cell Biol 2001, 21(18):6322-6331. 
27. Node K, Huo YQ, Ruan XL, Yang BC, Spiecker M, Ley K, Zeldin DC, Liao JK: Anti-inflammatory properties of cytochrome P450 epoxygenase-derived eicosanoids. Science 1999, 285:1276-1279.

28. Hampson AJ, Grimaldi M: 12-hydroxyeicosatetrenoate (12-HETE) attenuates AMPA receptor-mediated neurotoxicity: evidence for a Gprotein-coupled HETE receptor. J Neurosci 2002, 22(1):257-264.

29. Abdu E, Bruun DA, Yang D, Yang J, Inceoglu B, Hammock BD, Alkayed NJ, Lein PJ: Epoxyeicosatrienoic acids enhance axonal growth in primary sensory and cortical neuronal cell cultures. J Neurochem 2011, 117(4):632-642.

30. Brenneis C, Sisignano M, Coste O, Altenrath K, Fischer MJ, Angioni C, Fleming I, Brandes RP, Reeh PW, Woolf CJ, et al: Soluble epoxide hydrolase limits mechanical hyperalgesia during inflammation. Mol Pain 2011, 7:78.

31. Inceoglu B, Wagner K, Schebb NH, Morisseau C, Jinks SL, Ulu A, Hegedus C, Rose T, Brosnan R, Hammock BD: Analgesia mediated by soluble epoxide hydrolase inhibitors is dependent on CAMP. Proc Natl Acad Sci U S A 2011, 108(12):5093-5097

32. Sisignano M, Park CK, Angioni C, Zhang DD, von Hehn C, Cobos EJ, Ghasemlou N, Xu ZZ, Kumaran V, Lu R, et al: 5,6-EET is released upon neuronal activity and induces mechanical pain hypersensitivity via TRPA1 on central afferent terminals. J Neurosci 2012, 32(18):6364-6372.

33. Terashvili M, Tseng LF, Wu HE, Narayanan J, Hart LM, Falck JR, Pratt PF, Harder DR: Antinociception produced by 14,15-epoxyeicosatrienoic acid is mediated by the activation of beta-endorphin and met-enkephalin in the rat ventrolateral periaqueductal gray. J Pharmacol Exp Ther 2008, 326(2):614-622.

34. Wagner K, Inceoglu B, Hammock BD: Soluble epoxide hydrolase inhibition, epoxygenated fatty acids and nociception. Prostaglandins Other Lipid Mediat 2011, 96(1-4):76-83.

35. Wei EP, Lamb RG, Kontos HA: Increased phospholipase $C$ activity after experimental brain injury. J Neurosurg 1982, 56(5):695-698.

36. Homayoun P, Rodriguez deTurco EB, Parkins NE, Lane DC, Soblosky J, Carey ME, Bazan NG: Delayed phospholipid degradation in rat brain after traumatic brain injury. J Neurochem 1997, 69(1):199-205.

37. Phillis JW, O'Regan MH: A potentially critical role of phospholipases in central nervous system ischemic, traumatic, and neurodegenerative disorders. Brain Res Brain Res Rev 2004, 44(1):13-47.

38. Pilitsis JG, Coplin WM, O'Regan MH, Wellwood JM, Diaz FG, Fairfax MR, Michael DB, Phillis JW: Free fatty acids in cerebrospinal fluids from patients with traumatic brain injury. Neuroscience Letters 2003, 349(2):136-138.

39. Kontos HA, Wei EP, Ellis EF, Dietrich WD, Povlishock JT: Prostaglandins in physiological and in certain pathological responses of the cerebral circulation. Fed Proc 1981, 40(8):2326-2330.

40. Adesuyi SA, Cockrell CS, Gamache DA, Ellis EF: Lipoxygenase metabolism of arachidonic acid in brain. J Neurochem 1985, 45(3):770-776.

41. Shohami E, Shapira Y, Sidi A, Cotev S: Head injury induces increased prostaglandin synthesis in rat brain. J Cereb Blood Flow Metab 1987, 7(1):58-63.

42. Westcott JY, Murphy RC, Stenmark K: Eicosanoids in human ventricular cerebrospinal fluid following severe brain injury. Prostaglandins 1987, 34(6):877-887

43. Ellis EF, Police RJ, Rice LY, Grabeel M, Holt S: Increased plasma PGE2, 6-ketoPGF1 alpha, and 12-HETE levels following experimental concussive brain injury. J Neurotrauma 1989, 6(1):31-37.

44. Ohtsuki T, Matsumoto M, Hayashi Y, Yamamoto K, Kitagawa K, Ogawa S, Yamamoto S, Kamada T: Reperfusion induces 5-lipoxygenase translocation and leukotriene C4 production in ischemic brain. Am J Physiol 1995, 268(3 Pt 2):H1249-H1257.

45. Dhillon HS, Dose JM, Prasad MR: Regional generation of leukotriene C4 after experimental brain injury in anesthetized rats. J Neurotrauma 1996 13(12):781-789.

46. Lammers $\mathrm{CH}$, Schweitzer $P$, Facchinetti $P$, Arrang JM, Madamba SG, Siggins GR, Piomelli D: Arachidonate 5-lipoxygenase and its activating protein: prominent hippocampal expression and role in somatostatin signaling. J Neurochem 1996, 66(1):147-152.

47. Strauss KI, Barbe MF, Marshall RM, Raghupathi R, Mehta S, Narayan RK: Prolonged cyclooxygenase-2 induction in neurons and glia following traumatic brain injury in the rat. J Neurotrauma 2000, 17(8):695-711 [erratum appears in J Neurotrauma 2000 Nov;17(11):1115].

48. Kunz T, Marklund N, Hillered L, Oliw EH: Cyclooxygenase-2, prostaglandin synthases, and prostaglandin $\mathrm{H} 2$ metabolism in traumatic brain injury in the rat. J Neurotrauma 2002, 19(9):1051-1064.
49. Takemiya $T$, Matsumura $K$, Yamagata $K$ : Roles of prostaglandin synthesis in excitotoxic brain diseases. Neurochem Int 2007, 51(2-4):112-120.

50. Wang Y, Zhao J, Kalsotra A, Turman CM, Grill RJ, Dash PK, Strobel HW: CYP4Fs expression in rat brain correlates with changes in LTB4 levels after traumatic brain injury. J Neurotrauma 2008, 25(10):1187-1194.

51. Gopez JJ, Yue H, Vasudevan R, Malik AS, Fogelsanger LN, Lewis S, Panikashvili D, Shohami E, Jansen SA, Narayan RK, et al: Cyclooxygenase-2specific inhibitor improves functional outcomes, provides neuroprotection, and reduces inflammation in a rat model of traumatic brain injury. Neurosurgery 2005, 56(3):590-604.

52. Imaoka S, Hashizume T, Funae Y: Localization of rat cytochrome P450 in various tissues and comparison of arachidonic acid metabolism by rat P450 with that by human P450 orthologs. Drug Metab Pharmacokinet 2005, 20(6):478-484.

53. Liu M, Alkayed NJ: Hypoxic preconditioning and tolerance via hypoxia inducible factor (HIF) 1alpha-linked induction of P450 2C11 epoxygenase in astrocytes. J Cereb Blood Flow Metab 2005, 25(8):939-948.

54. Poloyac SM, Reynolds RB, Yonas H, Kerr ME: Identification and quantification of the hydroxyeicosatetraenoic acids, 20-HETE and 12HETE, in the cerebrospinal fluid after subarachnoid hemorrhage. J Neurosci Methods 2005, 144(2):257-263.

55. Sarkar P, Narayanan J, Harder DR: Differential effect of amyloid beta on the cytochrome P450 epoxygenase activity in rat brain. Neuroscience 2011, 194:241-249.

56. Ruparel S, Henry MA, Akopian A, Patil M, Zeldin DC, Roman L, Hargreaves KM: Plasticity of cytochrome P450 isozyme expression in rat trigeminal ganglia neurons during inflammation. Pain 2012, 153(10):2031-2039.

57. Strauss Kl, Gruzdev A, Zeldin DC: Improved functional recovery in soluble epoxide hydrolase knockout mice after traumatic brain injury. Prostaglandins Other Lipid Mediat 2012. in press.

58. Gibbs RA, Weinstock GM, Metzker ML, Muzny DM, Sodergren EJ, Scherer S, Scott G, Steffen D, Worley KC, Burch PE, et al: Genome sequence of the Brown Norway rat yields insights into mammalian evolution. Nature 2004, 428(6982):493-521

59. Ruparel S, Green D, Chen P, Hargreaves KM: The cytochrome P450 inhibitor, ketoconazole, inhibits oxidized linoleic acid metabolite-mediated peripheral inflammatory pain. Mol Pain 2012, 8:73.

60. Ellis EF, Wright KF, Wei EP, Kontos HA: Cyclooxygenase products of arachidonic acid metabolism in cat cerebral cortex after experimental concussive brain injury. J Neurochem 1981, 37(4):892-896.

61. Nagayama M, Niwa K, Nagayama T, Ross ME, ladecola C: The cyclooxygenase-2 inhibitor NS-398 ameliorates ischemic brain injury in wild-type mice but not in mice with deletion of the inducible nitric oxide synthase gene. J Cereb Blood Flow Metab 1999, 19(11):1213-1219.

62. Dash P, Mach S, Moore A: Regional expression and role of cyclooxygenase-2 following experimental traumatic brain injury. J Neurotrauma 2000, 17:69-81.

63. ladecola C, Niwa K, Nogawa S, Zhao X, Nagayama M, Araki E, Morham S, Ross ME: Reduced susceptibility to ischemic brain injury and N-methyl-Daspartate-mediated neurotoxicity in cyclooxygenase-2-deficient mice. Proc Natl Acad Sci U S A 2001, 98(3):1294-1299.

64. Candelario-Jalil E, Alvarez D, Castaneda JM, Al-Dalain SM, Martinez-Sanchez G, Merino N, Leon OS: The highly selective cyclooxygenase-2 inhibitor DFU is neuroprotective when given several hours after transient cerebral ischemia in gerbils. Brain Res 2002, 927(2):212-215.

65. Cernak I, O'Connor C, Vink R: Inhibition of cyclooxygenase 2 by nimesulide improves cognitive outcome more than motor outcome following diffuse traumatic brain injury in rats. Exp Brain Res 2002, 147(2):193-199.

66. Candelario-Jalil E, Mhadu NH, Gonzalez-Falcon A, Garcia-Cabrera M, Munoz E, Leon OS, Fiebich BL: Effects of the cyclooxygenase-2 inhibitor nimesulide on cerebral infarction and neurological deficits induced by permanent middle cerebral artery occlusion in the rat.

J Neuroinflammation 2005, 2(1):3.

67. Kelso ML, Scheff SW, Pauly JR, Loftin CD: Effects of genetic deficiency of cyclooxygenase- 1 or cyclooxygenase- 2 on functional and histological outcomes following traumatic brain injury in mice. BMC Neurosci 2009, 10:108.

68. Fathali N, Ostrowski RP, Lekic T, Jadhav V, Tong W, Tang J, Zhang JH: Cyclooxygenase-2 inhibition provides lasting protection against neonatal hypoxic-ischemic brain injury. Crit Care Med 2009. in press. 
69. Fathali N, Ostrowski RP, Lekic T, Jadhav V, Tong W, Tang J, Zhang JH: Cyclooxygenase- 2 inhibition provides lasting protection against neonatal hypoxic-ischemic brain injury. Crit Care Med 2010, 38(2):572-578.

70. Malik AS, Narayan RK, Wendling WW, Cole RW, Pashko LL, Schwartz AG, Strauss Kl: A novel dehydroepiandrosterone analog improves functional recovery in a rat traumatic brain injury model. J Neurotrauma 2003, 20(5):463-476

71. Strauss Kl, Meagher RJ, Narayan RK: Hippocampal prostaglandin changes following TBI- treatment with COX2 inhibitors. Restor Neurol Neurosci 2000, 16:263. P298.

72. Dewitt D, Kong D, Lyeth B, Jenkins L, Hayes R, Wooten E, Prough D: Experimental traumatic brain injury elevates brain prostaglandin E2 and thromboxane B2 levels in rats. J Neurotrauma 1988, 5:303-313.

73. Yergey JA, Heyes MP: Brain eicosanoid formation following acute penetration injury as studied by in vivo microdialysis. J Cerebr Blood Flow Metabol 1990, 10(1):143-146.

74. Ermert L, Ermert M, Duncker HR, Grimminger F, Seeger W: In situ localization and regulation of thromboxane A(2) synthase in normal and LPS-primed lungs. Am J Physiol Lung Cell Mol Physiol 2000, 278(4):L744-L753.

75. McDonough W, Tran N, Giese A, Norman SA, Berens ME: Altered gene expression in human astrocytoma cells selected for migration: I. Thromboxane synthase. J Neuropathol Exp Neurol 1998, 57(5):449-455.

76. Levi G, Minghetti L, Aloisi F: Regulation of prostanoid synthesis in microglial cells and effects of prostaglandin E2 on microglial functions. Biochimie 1998, 80(11):899-904.

77. Ramamurthy S, Mir F, Gould RM, Le Breton GC: Characterization of thromboxane $\mathrm{A} 2$ receptor signaling in developing rat oligodendrocytes: nuclear receptor localization and stimulation of myelin basic protein expression. J Neurosci Res 2006, 84(7):1402-1414

78. McCullough L, Wu L, Haughey N, Liang X, Hand T, Wang Q, Breyer RM, Andreasson K: Neuroprotective function of the PGE2 EP2 receptor in cerebral ischemia. J Neurosci 2004, 24(1):257-268.

79. Shi J, Johansson J, Woodling NS, Wang Q, Montine TJ, Andreasson K: The prostaglandin E2 E-prostanoid 4 receptor exerts anti-inflammatory effects in brain innate immunity. J Immunol 2010, 184(12):7207-7218.

80. Zhang J, Rivest S: Distribution, regulation and colocalization of the genes encoding the EP2- and EP4-PGE2 receptors in the rat brain and neuronal responses to systemic inflammation. Eur J Neurosci 1999, 11(8):2651-2668.

81. Bazan NG, Rodriguez de Turco EB, Allan G: Mediators of injury in neurotrauma: intracellular signal transduction and gene expression. J Neurotrauma 1995, 12(5):791-814.

82. Leslie JB, Watkins WD: Eicosanoids in the central nervous system. J Neurosurg 1985, 63(5):659-668.

83. Phillis JW, Horrocks LA, Farooqui AA: Cyclooxygenases, lipoxygenases, and epoxygenases in CNS: Their role and involvement in neurological disorders. Brain Res Rev 2006, 52(2):201-243.

84. Ashkar S, Mesentsev A, Zhang WX, Mastyugin V, Dunn MW, LaniadoSchwartzman M: Retinoic acid induces corneal epithelial CYP4B1 gene expression and stimulates the synthesis of inflammatory 12-hydroxyeicosanoids. J Ocul Pharmacol Ther 2004, 20(1):65-74.

85. Mastyugin V, Aversa E, Bonazzi A, Vafaes C, Mieyal P, Schwartzman ML: Hypoxia-induced production of 12-hydroxyeicosanoids in the corneal epithelium: involvement of a cytochrome P-4504B1 isoform. J Pharmacol Exp Ther 1999, 289(3):1611-1619.

86. Canals S, Casarejos MJ, de Bernardo S, Rodriguez-Martin E, Mena MA: Nitric oxide triggers the toxicity due to glutathione depletion in midbrain cultures through 12-lipoxygenase. J Biol Chem 2003, 278(24):21542-21549.

87. Chiba Y, Shimada A, Satoh M, Saitoh Y, Kawamura N, Hanai A, Keino H, Ide Y, Shimizu T, Hosokawa M: Sensory system-predominant distribution of leukotriene A4 hydrolase and its colocalization with calretinin in the mouse nervous system. Neuroscience 2006, 141(2):917-927.

88. Imaoka S, Wedlund PJ, Ogawa H, Kimura S, Gonzalez FJ, Kim HY: Identification of CYP2C23 expressed in rat kidney as an arachidonic acid epoxygenase. J Pharmacol Exp Ther 1993, 267(2):1012-1016.

89. Holla VR, Makita K, Zaphiropoulos PG, Capdevila JH: The kidney cytochrome P-450 2C23 arachidonic acid epoxygenase is upregulated during dietary salt loading. J Clin Invest 1999, 104(6):751-760.

90. Qian L, Zolfaghari R, Ross AC: Liver-specific cytochrome P450 CYP2C22 is a direct target of retinoic acid and a retinoic acid-metabolizing enzyme in rat liver. J Lipid Res 2010, 51(7):1781-1792.
91. Yu Z, Huse LM, Adler P, Graham L, Ma J, Zeldin DC, Kroetz DL: Increased CYP2J expression and epoxyeicosatrienoic acid formation in spontaneously hypertensive rat kidney. Mol Pharmacol 2000, 57(5):1011-1020.

92. Iliff JJ, Wang R, Zeldin DC, Alkayed NJ: Epoxyeicosanoids as mediators of neurogenic vasodilation in cerebral vessels. Am J Physiol Heart Circ Physiol 2009, 296(5):H1352-H1363.

93. Xu X, Zhang XA, Wang DW: The roles of CYP450 epoxygenases and metabolites, epoxyeicosatrienoic acids, in cardiovascular and malignant diseases. Adv Drug Deliv Rev 2011, 63(8):597-609.

94. Bolbrinker J, Beige J, Huber M, Sharma A, Thomas A, Deter H, Kreutz R: Role of CYP2C9 genetic variants for salt sensitivity and the regulation of the renin-angiotensin-aldosterone system in normotensive men. $J$ Hypertens 2011, 29(1):56-61.

95. Camara NO, Martins JO, Landgraf RG, Jancar S: Emerging roles for eicosanoids in renal diseases. Curr Opin Nephrol Hypertens 2009, 18(1):21-27.

96. Capdevila $\mathrm{JH}$ : Regulation of ion transport and blood pressure by cytochrome p450 monooxygenases. Curr Opin Nephrol Hypertens 2007, 16(5):465-470.

97. Simpson AE: The cytochrome P450 4 (CYP4) family. Gen Pharmacol 1997 28(3):351-359.

98. Ying CJ, Noguchi T, Aso H, Ikeda K, Yamori Y, Nara Y: The role of cytochrome p-450 in salt-sensitive stroke in stroke-prone spontaneously hypertensive rats. Hypertens Res 2008, 31(9):1821-1827.

99. Zhang F, Qian JQ, Wang DW: Arachidonate CYP hydroxylases of kidney contribute to formation of hypertension and maintenance of blood pressure. Acta Pharmacol Sin 2002, 23(6):497-502.

100. Dunn KM, Renic M, Flasch AK, Harder DR, Falck J, Roman RJ: Elevated production of 20-HETE in the cerebral vasculature contributes to severity of ischemic stroke and oxidative stress in spontaneously hypertensive rats. Am J Physiol Heart Circ Physiol 2008, 295(6):H2455-H2465.

101. Wang MH, Guan H, Nguyen X, Zand BA, Nasjletti A, Laniado-Schwartzman M: Contribution of cytochrome P-450 4A1 and 4A2 to vascular 20-hydroxyeicosatetraenoic acid synthesis in rat kidneys. Am J Physiol 1999, 276(2 Pt 2):F246-F253.

102. Hoch U, Zhang Z, Kroetz DL, Ortiz de Montellano PR: Structural determination of the substrate specificities and regioselectivities of the rat and human fatty acid omega-hydroxylases. Arch Biochem Biophys 2000, 373(1):63-71.

103. Zhang F, Chen CL, Qian JQ, Yan JT, Cianflone K, Xiao X, Wang DW: Long-term modifications of blood pressure in normotensive and spontaneously hypertensive rats by gene delivery of rAAV-mediated cytochrome P450 arachidonic acid hydroxylase. Cell Res 2005, 15(9):717-724

104. Zhang QY, Ding X, Kaminsky LS: CDNA cloning, heterologous expression, and characterization of rat intestinal CYP2J4. Arch Biochem Biophys 1997, 340(2):270-278.

105. Chuang SS, Helvig C, Taimi M, Ramshaw HA, Collop AH, Amad M, White JA, Petkovich M, Jones G, Korczak B: CYP2U1, a novel human thymus- and brain-specific cytochrome P450, catalyzes omega- and (omega-1)hydroxylation of fatty acids. J Biol Chem 2004, 279(8):6305-6314.

106. Kawashima $\mathrm{H}$, Kusunose $\mathrm{E}$, Thompson CM, Strobel HW: Protein expression, characterization, and regulation of CYP4F4 and CYP4F5 cloned from rat brain. Arch Biochem Biophys 1997, 347(1):148-154.

107. Xu F, Falck JR, Ortiz de Montellano PR, Kroetz DL: Catalytic activity and isoform-specific inhibition of rat cytochrome p450 4F enzymes. J Pharmacol Exp Ther 2004, 308(3):887-895.

108. Christmas P, Tolentino K, Primo V, Berry KZ, Murphy RC, Chen M, Lee DM, Soberman RJ: Cytochrome P-450 4F18 is the leukotriene B4 omega-1/ omega-2 hydroxylase in mouse polymorphonuclear leukocytes: identification as the functional orthologue of human polymorphonuclear leukocyte CYP4F3A in the down-regulation of responses to LTB4. J Biol Chem 2006, 281(11):7189-7196.

109. Mezentsev A, Mastyugin V, Seta F, Ashkar S, Kemp R, Reddy DS, Falck JR, Dunn MW, Laniado-Schwartzman M: Transfection of cytochrome P4504B1 into the cornea increases angiogenic activity of the limbal vessels. J Pharmacol Exp Ther 2005, 315(1):42-50.

110. Clark RS, Kochanek PM, Dixon CE, Chen M, Marion DW, Heineman S, DeKosky ST, Graham SH: Early neuropathologic effects of mild or moderate hypoxemia after controlled cortical impact injury in rats. J Neurotrauma 1997, 14(4):179-189. 
111. Conti AC, Raghupathi R, Trojanowski JQ, Mclntosh TK: Experimental brain injury induces regionally distinct apoptosis during the acute and delayed post-traumatic period. J Neurosci 1998, 18(15):5663-5672.

112. Raghupathi R, Graham DI, McIntosh TK: Apoptosis after traumatic brain injury. J Neurotrauma 2000, 17(10):927-938.

113. Bylund J, Zhang C, Harder DR: Identification of a novel cytochrome P450, CYP4X1, with unique localization specific to the brain. Biochem Biophys Res Commun 2002, 296(3):677-684.

114. Stark K, Dostalek M, Guengerich FP: Expression and purification of orphan cytochrome P450 4X1 and oxidation of anandamide. FEBS J 2008, 275(14):3706-3717.

115. Snider NT, Walker VJ, Hollenberg PF: Oxidation of the endogenous cannabinoid arachidonoyl ethanolamide by the cytochrome P450 monooxygenases: physiological and pharmacological implications. Pharmacol Rev 2010, 62(1):136-154.

116. Hansen HS: Palmitoylethanolamide and other anandamide congeners. Proposed role in the diseased brain. Exp Neurol 2010, 224(1):48-55.

117. Shohami E, Cohen-Yeshurun A, Magid L, Algali M, Mechoulam R: Endocannabinoids and traumatic brain injury. Br J Pharmacol 2011, 163(7):1402-1410.

118. Mateos L, Ismail MA, Gil-Bea FJ, Schule R, Schols L, Heverin M, Folkesson R, Bjorkhem I, Cedazo-Minguez A: Side chain-oxidized oxysterols regulate the brain renin-angiotensin system through a liver $X$ receptordependent mechanism. J Biol Chem 2011, 286(29):25574-25585.

119. Shaw PM, Adesnik M, Weiss MC, Corcos L: The phenobarbital-induced transcriptional activation of cytochrome P-450 genes is blocked by the glucocorticoid-progesterone antagonist RU486. Mol Pharmacol 1993, 44(4):775-783.

120. Rifkind $A B$, Lee $C$, Chang TK, Waxman DJ: Arachidonic acid metabolism by human cytochrome P450s $2 \mathrm{C} 8,2 \mathrm{C} 9,2 \mathrm{E} 1$, and $1 \mathrm{~A} 2$ : regioselective oxygenation and evidence for a role for CYP2C enzymes in arachidonic acid epoxygenation in human liver microsomes. Arch Biochem Biophys 1995, 320(2):380-389

121. Bylund J, Kunz T, Valmsen K, Oliw EH: Cytochromes P450 with bisallylic hydroxylation activity on arachidonic and linoleic acids studied with human recombinant enzymes and with human and rat liver microsomes. J Pharmacol Exp Ther 1998, 284(1):51-60.

122. Michaelis UR, Fisslthaler B, Barbosa-Sicard E, Falck JR, Fleming I, Busse R: Cytochrome P450 epoxygenases 2C8 and 2C9 are implicated in hypoxiainduced endothelial cell migration and angiogenesis. J Cell Sci 2005, 118(Pt 23):5489-5498.

123. Laethem RM, Balazy M, Falck JR, Laethem CL, Koop DR: Formation of 19(S)-, 19(R)-, and 18(R)-hydroxyeicosatetraenoic acids by alcohol-inducible cytochrome P450 2E1. J Biol Chem 1993, 268(17):12912-12918.

124. Tindberg N, Ingelman-Sundberg M: Expression, catalytic activity, and inducibility of cytochrome P450 2E1 (CYP2E1) in the rat central nervous system. J Neurochem 1996, 67(5):2066-2073.

125. Nissbrandt H, Bergquist F, Jonason J, Engberg G: Inhibition of cytochrome P450 2E1 induces an increase in extracellular dopamine in rat substantia nigra: a new metabolic pathway? Synapse 2001, 40(4):294-301.

126. Bromek E, Haduch A, Daniel WA: The ability of cytochrome P450 2D isoforms to synthesize dopamine in the brain: An in vitro study. Eur J Pharmacol 2010, 626(2-3):171-178

127. Bromek E, Haduch A, Golembiowska K, Daniel WA: Cytochrome P450 mediates dopamine formation in the brain in vivo. J Neurochem 2011, 118(5):806-815.

128. Mclntosh TK, Yu T, Gennarelli TA: Alterations in regional brain catecholamine concentrations after experimental brain injury in the rat. J Neurochem 1994, 63(4):1426-1433.

129. Hernandez RE, Putzke AP, Myers JP, Margaretha L, Moens CB: Cyp26 enzymes generate the retinoic acid response pattern necessary for hindbrain development. Development 2007, 134(1):177-187.

130. Gonzalez-Quevedo R, Lee Y, Poss KD, Wilkinson DG: Neuronal regulation of the spatial patterning of neurogenesis. Dev Cell 2010, 18(1):136-147.

131. Bowles J, Knight D, Smith C, Wilhelm D, Richman J, Mamiya S, Yashiro K, Chawengsaksophak K, Wilson MJ, Rossant J, et al: Retinoid signaling determines germ cell fate in mice. Science 2006, 312(5773):596-600.

132. Wang C, Kane MA, Napoli JL: Multiple retinol and retinal dehydrogenases catalyze all-trans-retinoic acid biosynthesis in astrocytes. J Biol Chem 2011, 286(8):6542-6553.

133. Hagglund M, Berghard A, Strotmann J, Bohm S: Retinoic acid receptordependent survival of olfactory sensory neurons in postnatal and adult mice. J Neurosci 2006, 26(12):3281-3291.
134. Gilep AA, Sushko TA, Usanov SA: At the crossroads of steroid hormone biosynthesis: the role, substrate specificity and evolutionary development of CYP17. Biochim Biophys Acta 2011, 1814(1):200-209.

135. Hojo Y, Hattori TA, Enami T, Furukawa A, Suzuki K, Ishii HT, Mukai H, Morrison $\mathrm{JH}$, Janssen WG, Kominami S, et al: Adult male rat hippocampus synthesizes estradiol from pregnenolone by cytochromes P45017alpha and P450 aromatase localized in neurons. Proc Natl Acad Sci U S A 2004, 101(3):865-870.

136. Kibaly C, Patte-Mensah C, Mensah-Nyagan AG: Molecular and neurochemical evidence for the biosynthesis of dehydroepiandrosterone in the adult rat spinal cord. J Neurochem 2005, 93(5):1220-1230.

137. Kimoto $T$, Ishii H, Higo S, Hojo Y, Kawato S: Semicomprehensive analysis of the postnatal age-related changes in the mRNA expression of sex steroidogenic enzymes and sex steroid receptors in the male rat hippocampus. Endocrinology 2010, 151(12):5795-5806.

138. García-Estrada J, Luquin S, Fernandez AM, Garcia-Segura LM: Dehydroepiandrosterone, pregnenolone and sex steroids down-regulate reactive astroglia in the male rat brain after a penetrating brain injury. Int J Dev Neurosci 1999, 17(2):145-151.

139. Roof RL, Hall ED: Gender differences in acute CNS trauma and stroke: neuroprotective effects of estrogen and progesterone. J Neurotrauma 2000, 17(5):367-388

140. Stein DG, Hoffman SW: Estrogen and progesterone as neuroprotective agents in the treatment of acute brain injuries. Pediatr Rehabil 2003, 6(1):13-22.

141. He J, Evans CO, Hoffman SW, Oyesiku NM, Stein DG: Progesterone and allopregnanolone reduce inflammatory cytokines after traumatic brain injury. Exp Neurol 2004, 189(2):404-412.

142. Stein DG, Wright DW: Progesterone in the clinical treatment of acute traumatic brain injury. Expert Opin Investig Drugs 2010, 19(7):847-857.

143. Hoffman SW, Virmani S, Simkins RM, Stein DG: The delayed administration of dehydroepiandrosterone sulfate improves recovery of function after traumatic brain injury in rats. J Neurotrauma 2003, 20(9):859-870.

144. Li Z, Cui S, Zhang Z, Zhou R, Ge Y, Sokabe M, Chen L: DHEAneuroprotection and -neurotoxicity after transient cerebral ischemia in rats. J Cereb Blood Flow Metab 2009, 29(2):287-296.

145. Tehranipour M, Moghimi A: Neuroprotective effects of testosterone on regenerating spinal cord motoneurons in rats. J Mot Behav 2010, 42(3):151-155.

146. Nguyen TV, Jayaraman A, Quaglino A, Pike CJ: Androgens selectively protect against apoptosis in hippocampal neurones. J Neuroendocrinol 2010, 22(9):1013-1022

147. Toung TJ, Traystman RJ, Hurn PD: Estrogen-mediated neuroprotection after experimental stroke in male rats. Stroke 1998, 29(8):1666-1670.

148. Garcia-Segura LM, Naftolin F, Hutchison JB, Azcoitia I, Chowen JA: Role of astroglia in estrogen regulation of synaptic plasticity and brain repair [99 refs]. J Neurobiol 1999, 40(4):574-584.

149. McCullough LD, Blizzard K, Simpson ER, Oz OK, Hurn PD: Aromatase cytochrome P450 and extragonadal estrogen play a role in ischemic neuroprotection. J Neurosci 2003, 23(25):8701-8705.

150. Li J, Siegel M, Yuan M, Zeng Z, Finnucan L, Persky R, Hurn PD, McCullough LD: Estrogen enhances neurogenesis and behavioral recovery after stroke. J Cereb Blood Flow Metab 2011, 31(2):413-425.

151. Bustin SA, Benes V, Garson JA, Hellemans J, Huggett J, Kubista M, Mueller R, Nolan T, Pfaffl MW, Shipley GL, et al: The MIQE guidelines: minimum information for publication of quantitative real-time PCR experiments. Clin Chem 2009, 55(4):611-622.

152. Yuan JS, Reed A, Chen F, Stewart CN Jr: Statistical analysis of real-time PCR data. BMC Bioinformatics 2006, 7:85

153. Livak KJ, Schmittgen TD: Analysis of relative gene expression data using real-time quantitative PCR and the 2(-Delta Delta $C(T)$ ) Method. Methods 2001, 25(4):402-408.

154. Schmittgen TD, Livak KJ: Analyzing real-time PCR data by the comparative C(T) method. Nat Protoc 2008, 3(6):1101-1108.

155. Paxinos G, Watson C: The rat brain in stereotaxic coordinates. San Diego: Academic; 1986

156. Strauss K, Jacobowitz D: Quantitative measurement of calretinin and b-actin mRNA in rat brain micropunches without prior isolation of RNA. Mol Brain Res 1993, 20(3):229-239.

doi:10.1186/1471-2164-14-303

Cite this article as: Birnie et al:: Temporal changes of cytochrome P450 (Сур) and eicosanoid-related gene expression in the rat brain after traumatic brain injury. BMC Genomics 2013 14:303. 